\title{
A wider view of assessments of ecosystem services in coastal areas: the perspective of social-ecological complexity
}

\author{
$\underline{\text { Liliana Solé }}^{1}$ and Eduard Ariza ${ }^{1}$
}

ABSTRACT. Through complex interactions and feedback processes between coastal ecological and social components at different temporal and spatial scales, coastal environments coproduce a range of ecosystem services (ES) and benefit different social groups. In these highly populated areas, multiple actors, interests, and activities coexist, leading to intensified conflicts between stakeholders. The research presented here aims to understand how coastal social-ecological complexity is studied within coastal ES literature. A systematic review of the literature consisting of 199 manuscripts was performed using the PRISMA method (Preferred Reporting Items for Systematic Reviews and Meta-Analyses). The results show that coastal ES research has been focused on understanding ecological processes for ES provision and value. Hence, coastal ES studies fall short of considering the social components and social-ecological interactions of coastal systems: ES flows, demand, coproduction, power relations, institutions and governance, temporal and spatial scales, value pluralism, uncertainty, and human well-being multidimensions and distribution. The partial integration of social-ecological complexity within coastal ES research limits coastal ES management because nonlinear interactions among social and ecological components are not well understood, particularly stakeholders' relations, their roles, and the links to ES. Finally, we propose a conceptual framework that integrates the gaps identified during the review. The framework places coproduction and power relations as the core factors of assessments of coastal ES, as means to understand complex, nonlinear social-ecological interactions and feedback processes. Hence, it also provides necessary tools to address normative issues of coastal management such as control, access, trade-offs, and benefits.

Key Words: coastal ecosystem services; coastal social-ecological complexity; coproduction; human well-being; power; systematic literature review

\section{INTRODUCTION}

In the last decade, several ecosystem services (ES) frameworks have been developed aiming to comprehend social-ecological system (SES) complexity such as the following: (1) the Millennium Ecosystem Assessment (MEA; Millennium Ecosystem Assessment 2005), which focuses on the links between ecosystem change and human well-being; (2) The cascade model (Haines-Young and Potschin 2009), which represents a "production line" from biophysical structures and processes to components of human well-being through a series of intermediate stages; (3) The Economics of Ecosystems and Biodiversity (TEEB; de Groot et al. 2010), which pays particular attention to the economic benefits of biodiversity and ecosystem services, and the costs linked with their damage (Baral et al. 2016); (4) The Intergovernmental Platform on Biodiversity and Ecosystem Services (IPBES) (Díaz et al. 2015), which aims to bridge the science-policy gap by seeking to support decision making on how to stop the further degradation of ecosystems (Baral et al. 2016); and (5) The ES capacity and flow models (Villamagna et al. 2013, Burkhard et al. 2014), which look to spatial distribution and assessment of capacity, flow, and demand as means to inform policy making on potential ES mismatches (Geijzendorffer et al. 2015).

ES frameworks are set within a linear-cyclical approach, i.e., the flow from ecosystems to human benefits (Jones et al. 2016). This linear flow is composed of different parts; "the potential of an ecosystem to deliver an ecosystem service," in this paper called capacity (Villamagna et al. 2013:116), "ecosystem services in point of fact received by people," in this paper called flow (Villamagna et al. 2013:116), contributions to aspects of human well-being, in this paper called benefit (Potschin and Hainesyoung 2016), the criteria used by people to assign importance to things, in this paper called value (Potschin and Haines-young 2016), and "the total amount of service needed or desired by society," in this paper called demand (Villamagna et al. 2013:116). The cyclical part of ES frameworks generally includes natural or human-induced drivers, such as decision making and management, which in turn affect ecosystems and their flow (Van Oudenhoven et al. 2012).

ES frameworks acknowledge that humans are part of the environment and their role in ES is increasingly recognized (Burkhard et al. 2014, Jones et al. 2016). However, the social dimension, stakeholders' relations, and their roles, are still not sufficiently understood (Geijzendorffer et al. 2015). In this vein, the role of humans as coproducers at different stages in the process of ecosystem service delivery is still uncertain (Jones et al. 2016).

Improvement is needed to understand ES coproduction processes (Palomo et al. 2016), i.e., identifying and analyzing the natural and non-natural components and their interactions such as knowledge, infrastructures, technology, institution arrangements, governance systems, and social representations. Hence, grasping the processes that make up a service, which are also embedded in past social and cultural legacies (Church et al. 2011, Outeiro et al. 2017). Sustainable environmental management needs to embrace the complexity of ES coproduction processes, to acknowledge when and how non-natural components assist or even substitute natural components (Palomo et al. 2016). Furthermore, from an environmental-justice perspective, because certain human inputs and processes are demanded to coproduce ecosystem services, questions arise regarding the equal distribution and access of these inputs and related ecosystem services (Fischer and Eastwood 2016). 
Importantly, a fundamental aspect of the coproduction of ecosystem services is power (Felipe-Lucía et al. 2015). Power is embedded within institutional arrangements and governance systems, i.e., all formal and informal social organization systems and processes (Díaz et al. 2015). The interactions and feedbacks between biophysical processes and power relations embedded within institutional and governance systems (alongside knowledge, infrastructures, technology, and social representations) shape the coproduction process of ecosystems services. Power relations shape not only the coproduction of ES, but which actors or groups benefit from those ES (Ernstson 2013). For example, the creation of terrestrial protected areas has, in some cases, excluded local communities and traditional uses in favor of recreation or ecotourism (Berbés-Blázquez et al. 2016). Such management decisions and linked trade-offs respond to certain institutional arrangements and governance processes shaped by power, which define ES access and benefit distribution, i.e., winners and losers. Thus, trade-offs between different ES also lead to trade-offs between the well-being of different social groups (Daw et al. 2011).

Human well-being (HWB) is as a "positive physical, social and mental state" (Summers et al. 2012:328). It is the outcome of social processes, and varies with space and time (Jax and Heink 2016). Actors might have different access to ES benefits and hence to HWB, or they might hold different conceptions of benefits to HWB (Butler and Oluoch-Kosura 2006, ESPA 2018). Local fishing communities may consider symbolic spaces to be part of the benefits for HWB, while other larger fishing companies may not consider these symbolic spaces to be relevant for HWB. Furthermore, well-being benefits might vary depending on spatial and temporal scales. On a global scale, marine protected areas produce benefits to humanity (enhance biodiversity), but at smaller temporal and spatial scales these can have little benefit or be costly for local communities, or they might need more time to be enjoyed by local communities (Daw et al. 2016). In fact, social-ecological systems are characterized by multiscale and cross-scale interactions and feedbacks, and hence, ecosystem services and associated benefits can be coproduced, used, and valued, all at different spatial and temporal scales (Scholes et al. 2013). Hence, HWB is multidimensional, dynamic across time and space and context-dependent (Narayan et al. 2000, Pereira et al. 2005, Adams et al. 2016). Consequently, ES assessments cannot aggregate wellbeing, i.e., considering humanity as a homogeneous group. ES assessments need to develop a disaggregate analysis (Daw et al. 2011). They ought to account for multidimensional aspects of wellbeing among different social groups integrating intrinsic, instrumental, and relational aspects (Díaz et al. 2015) and assessing different value dimensions (monetary, ecological, and sociocultural; Jacobs et al. 2016, 2018). Disaggregate approaches must also include distributional spatial patterns and scale-context dependencies.

HWB is maintained through the accomplishment of fundamental human needs (Max-Neef et al. 1998). These needs are constant across time and space, but the means of accomplishing them vary depending on socio-cultural contexts (McGregor 2010). Therefore, this perspective embraces well-being dynamism, and context and scale dependency. Max-Neef's universal needs are divided into two categories: existential (four needs) and axiological (nine needs). Existential needs refer to experiences, i.e., needs to be, do, have and interact, while axiological needs relate to values that humans hold.
Hence, humans will be, do, have and interact to achieve needs that they value (McGregor 2010). Remarkably, individuals are beings of multiple and interconnected needs that work as a system. Therefore, HWB not only depends on the satisfaction of subsistence needs, but also on multiple interrelated dimensions of well-being: the objective, subjective, and relational dimensions of well-being.

All the above-mentioned aspects of social-ecological system (SES) complexity are embedded with uncertainty, which is an essential characteristic of social-ecological systems (Hou et al. 2013). Hence, because of their high complexity, ES carry remarkable levels of uncertainty and generalization (Scolozzi et al. 2012), which comes from different sources (Grêt-Regamey et al. 2013, Hou et al. 2013). These sources include the complexity of natural and social systems (inherent variability of ecological and social processes that underpin the services function), the complexity of social-ecological interactions (variability of social-ecological interactions that support ES provision), the complexity of values and HWB conceptions (multiple understanding of what to value and HWB), the imperfection or limitation of knowledge (how much we know and understand), the deficiency of valuations and assessment methods (every method transfers a certain degree of uncertainty to the results; Hou et al. 2013), and technical uncertainty (intrinsic probability of error in the results).

\section{ES in coastal areas}

Coastal zones are highly complex social-ecological systems resulting from the land and sea interface (Turner and Schaafsma 2015). This interface is characterized by interactions, synergies, and trade-offs between marine and terrestrial systems, e.g., the use of fertilizers in agriculture increases productivity, but means there is a nutrient surplus flowing to the sea, producing eutrophication (Millennium Ecosystem Assessment 2005, Turner and Schaafsma 2015). The outcomes of these interactions are the products of a vast number of important, even unique, ecosystem services that directly or indirectly underpin human activities (Zaucha et al. 2016)

Much of the world's social, cultural, and economic development is concentrated within coastal zones. Consequently, they contain multiple and overlapping actors, activities, interests, values, and human well-being conceptions (Bremer 2011) which lead to conflict between stakeholder groups (Sas et al. 2010, Portman 2013). These, in turn, are all articulated through institutions and governance processes. Therefore, multiple governance tools and institutions aim to administer over the same space, but these are horizontally (sectorial division) or vertically fragmented (subnational, national, regional, and local divisions; Powell et al. 2009, Sardà et al. 2014). In addition, the above-mentioned fragmentations do not usually correspond to the spatial and temporal scales of coastal-system components and processes.

The complexity of coastal social-ecological systems also generates vast uncertainty, which is intensified by the lack of or limited knowledge of coastal and marine areas (Liquete et al. 2013, Zaucha et al. 2016), and which affects our understanding of current and future marine and terrestrial interactions, synergies, and trade-offs. Consequently, there are still important knowledge limitations regarding climate-change effects, decision making, and management. 
Coastal ES research informs and enables coastal management. The omission of SES complexity diminishes management debates and interventions because nonlinear interactions and feedbacks among social and ecological components are partially understood, especially stakeholders' relations, their roles, and the links to ES. In this context, coastal ES assessment poses the particular need to take SES complexity into consideration. Through a systematic literature review, we study how coastal SES complexity is taken into account within coastal ES literature by (1) analyzing coastal SES complexity factors within coastal ES literature: integration of ecological and social components, ES coproduction, institutions and governance, power relations, uncertainty, spatial scales, value pluralism, and HWB links; (2) identifying gaps regarding social-ecological complexity within coastal ES literature; and (3) proposing a framework for coastal ES social-ecological complexity for future research by highlighting societal aspects as central components of the ES framework.

\section{METHODS}

This systematic literature review follows the PRISMA statement (Preferred Reporting Items for Systematic Reviews and MetaAnalyses; Moher et al. 2009) to enhance robustness. The PRISMA statement provides a flow diagram and a checklist that are both used as a guide for the review process.

\section{Literature search}

To identify relevant literature, a bibliographic search of the Scopus database was conducted. Only papers explicitly using the concept of ecosystem services have been considered. The bibliographical search ${ }^{[1]}$ was limited to any peer-reviewed publication published from 1998 to December 2017 with the following terms in the title, keywords, or abstract, "ecosystem service" or "environmental service," and "coastal" or "littoral," and coastal habitats in all fields, including singular and plural forms of all key words. Coastal habitats were defined based on Liquete et al. (2013) European nature information system (EUNIS), and The Coastal and Marine Ecological Classification Standard (CMECS) classifications. A total of 373 papers were found, 366 after removing duplicates (Fig. 1).

\section{Selection criteria}

The selection criteria defined for this review were the following: (1) evaluate/conceptualize/map/quantify/value coastal ecosystems; (2) publications in refereed journals; (3) publications written in English; and (4) papers on locations in a specific coastal area, between 1 kilometer from the upper boundary of the coastline and the outer limit of territorial waters (12 nautical miles). This boundary corresponds to the space generally included in many regulatory coastal frameworks (Ariza et al. 2016). Taking these criteria into account and following the PRISMA statement, titles and abstracts of 366 publications were reviewed, resulting in the rejection of 117 because they were not related to coastal ecosystem services. The next full text screening was performed, discarding 50 publications because they use the term ecosystem service as justification or introduction (for example, in the first sentences of the abstract or introduction, to contextualize or justify environmental research) without addressing the issue. ES has become a modish concept and is often cited as a reason for the research or as a fashionable keyword, but without being particularly applied or assessed (Liquete et al. 2013). The total final number of articles was 199.
Fig. 1. PRISMA (Preferred Reporting Items for Systematic Reviews and Meta-Analyses) flow

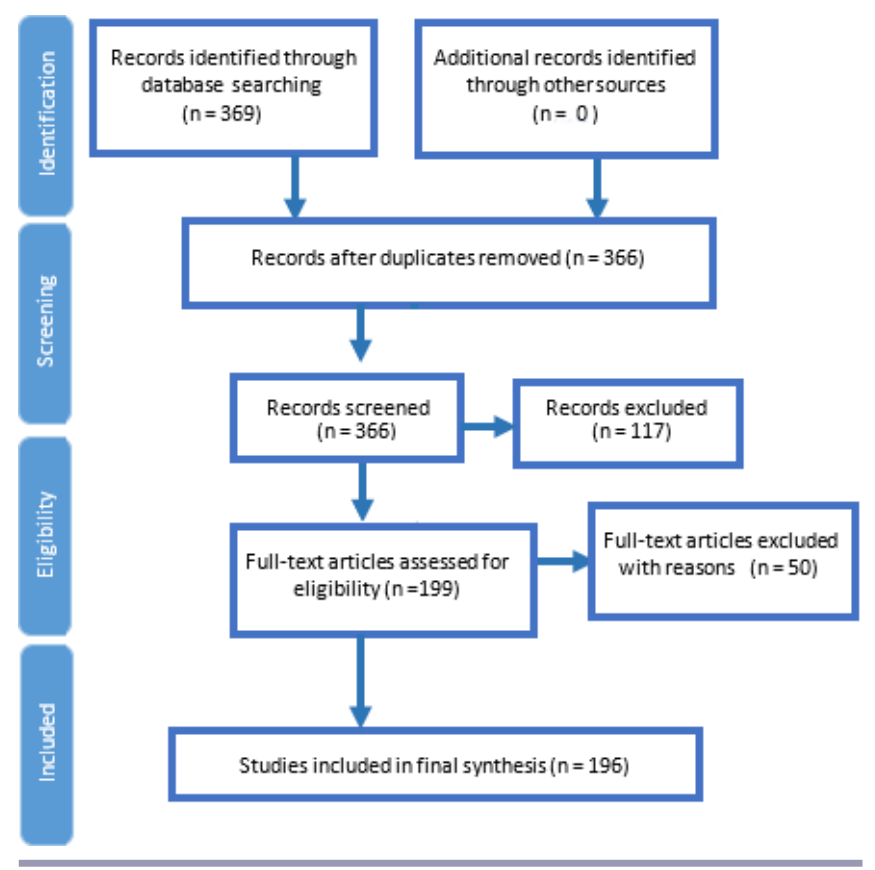

Data collection and analysis

The data in the systematic review included thirty variables and their corresponding response categories (Table 1) to assess the social-ecological complexity of coastal ES. One of the variables analyzed is HWB. To that aim we use the Max-Neef matrix (MaxNeef et al. 1998) because it provides the necessary tools to analyze well-being as multidimensional, dynamic, and context and scale dependent. It is composed of nine axiological human needs, namely, subsistence, protection, affection, understanding, participation, leisure, creation, identity, and freedom, and four existential categories of human needs, namely, being (qualities), having (things), doing (actions), and interacting (settings). Using the above-mentioned categories, Max-Neef created a 36-cell matrix. Each of these cells is completed with satisfiers, processes by which people can achieve axiological and existential needs. The data collected was analyzed using descriptive statistics. A table was made to summarize the results (see Table A1.1 in Appendix 1).

\section{RESULTS}

Since 2006, there has been an exponential increase in assessments of coastal ES, which have mainly focused on provision and regulating services (Liquete et al. 2013). Furthermore, assessments of coastal ES have targeted ecological and economic aspects, commonly through quantitative analysis. Our results show that even though these features of ES assessments are still valid, there are some changing trends: an increasing interest in cultural services, mainly in recreation services, whereas symbolic and aesthetic values and cognitive effects are often omitted or relegated to the background. The literature review also reveals a growing interest in the social aspects of ES, such as the human impact on ES conditions and rising qualitative and mixed analyses (combining quantitative and qualitative methodologies), 
Table 1. Data variables and categories for data collection.

\begin{tabular}{|c|c|c|c|}
\hline & Definition & Variables & Categories \\
\hline \multirow{10}{*}{$\begin{array}{l}\text { General } \\
\text { information }\end{array}$} & Paper's descriptive and contextual information & Year & E.g., 1999; 2003 \\
\hline & & Author & E.g., Barbier; Costanza \\
\hline & & Institution of first author & E.g., Cardiff University; University of Wyoming \\
\hline & & $\begin{array}{l}\text { Country of first author's } \\
\text { institution }\end{array}$ & E.g., USA; Denmark \\
\hline & & Location of the study & E.g., France; USA \\
\hline & & Costal ecosystem services (ES) & E.g., provisioning; regulation and maintenance; cultural \\
\hline & & Coastal ES category & $\begin{array}{l}\text { Classification by Liquete et al., (2013) that integrates and } \\
\text { harmonizes most common classifications, and provides a } \\
\text { cross-reference table. }\end{array}$ \\
\hline & & & E.g., food provision; climate regulation; recreation. \\
\hline & & Type of habitat & E.g., dune; beach; mangroves; seagrass \\
\hline & & Type of study area & E.g., coastal; marine; terrestrial \\
\hline \multirow[t]{3}{*}{$\begin{array}{l}\text { Ecological and } \\
\text { social systems }\end{array}$} & $\begin{array}{l}\text { Links between ecological and social components of } \\
\text { SES }\end{array}$ & $\begin{array}{l}\text { Does the article assess the } \\
\text { cascade model components? }\end{array}$ & $\begin{array}{l}\text { Capacity as the potential of an ecosystem to deliver an } \\
\text { ecosystem service (Villamagna et al. 2013). Flow as service } \\
\text { in point of fact received by people (service delivered; } \\
\text { Villamagna et al. 2013). Benefit as contributions to aspects } \\
\text { of human well-being (Potschin and Haines-Young 2016). } \\
\text { Value as the criteria used by people to assign importance } \\
\text { to things (Potschin and Haines-Young 2016). }\end{array}$ \\
\hline & & $\begin{array}{l}\text { Does the article explicitly assess } \\
\text { demand? }\end{array}$ & $\begin{array}{l}\text { Demand as the total amount of service needed or desired } \\
\text { by society (Villamagna et al. 2013). }\end{array}$ \\
\hline & & $\begin{array}{l}\text { Does the article assess the } \\
\text { differences between capacity, } \\
\text { flow, and demand? }\end{array}$ & $\begin{array}{l}\text { Assessment of (un)sustainable uptake or (un)satisfied } \\
\text { demand of ES (Villamagna et al. 2013, Baró et al. 2016). }\end{array}$ \\
\hline \multirow[t]{4}{*}{ Coproduction } & $\begin{array}{l}\text { Contributions of natural and non-natural inputs to } \\
\text { the provision of ES. These contributions take place } \\
\text { in the present and throughout time (heritages of } \\
\text { past and present societies; Church et al. 2014, } \\
\text { Outeiro et al. 2017) }\end{array}$ & Historical analysis & Yes; No \\
\hline & & Time frame & $\begin{array}{l}\text { Long term }(+1 \text { year }) . \text { Medium term }(-1 \text { year }) \text {. Short term } \\
(1 \text { month or less })\end{array}$ \\
\hline & & $\begin{array}{l}\text { Does the paper study drivers of } \\
\text { change affecting coastal ES }\end{array}$ & $\begin{array}{l}\text { E.g., land use change; urbanization; eutrophication; } \\
\text { overfishing }\end{array}$ \\
\hline & & $\begin{array}{l}\text { Does the paper link coastal ES } \\
\text { to legislative frameworks, } \\
\text { institutions, knowledge, } \\
\text { technology, and values? }\end{array}$ & Yes; No \\
\hline \multirow[t]{5}{*}{$\begin{array}{l}\text { Institutional } \\
\text { arrangements and } \\
\text { governance systems }\end{array}$} & $\begin{array}{l}\text { All structures and process of social organization. } \\
\text { Institutions include all formal and informal human } \\
\text { relations and structures that define human } \\
\text { behaviors. Governance systems are interacting } \\
\text { bundles of institutions at different spatial scales } \\
\text { (from local to regional; Diaz et al. 2015). }\end{array}$ & Identification of actors involved & Yes; No \\
\hline & & $\begin{array}{l}\text { Does the article identify and } \\
\text { analyze institutional } \\
\text { arrangements (formal and } \\
\text { informal)? }\end{array}$ & Yes; No \\
\hline & & $\begin{array}{l}\text { Does the article identify and } \\
\text { analyze institutional governance } \\
\text { systems? }\end{array}$ & Yes; No \\
\hline & & $\begin{array}{l}\text { Does the article study links } \\
\text { between institutions or } \\
\text { governance structures and } \\
\text { coastal ES in terms of supply, } \\
\text { delivery, use, and access? }\end{array}$ & $\begin{array}{l}\text { E.g., property rights of specific areas; traditional } \\
\text { agreements between local communities to access certain } \\
\text { ES or areas. }\end{array}$ \\
\hline & & $\begin{array}{l}\text { Does the article identify and } \\
\text { analyze conflicts between } \\
\text { informal and formal } \\
\text { institutional arrangements? }\end{array}$ & $\begin{array}{l}\text { Informal agreements between coastal local communities } \\
\text { vs. national regulations limiting fishing activities }\end{array}$ \\
\hline Power relations & $\begin{array}{l}\text { Unequal power relations support the production, } \\
\text { distribution, and access of ES (Berbés-Blázquez et } \\
\text { al. 2016), i.e., which actors have access to ES and } \\
\text { how do they benefit from them, what interests are } \\
\text { prioritized or excluded, what values are at stake, } \\
\text { and also how value preferences are defined. }\end{array}$ & Identification of actors involved & E.g., fishermen, tourists, inhabitants \\
\hline
\end{tabular}


Temporal and
spatial scales

Value pluralism

Uncertainty
ES are produced, supplied, used, managed, and valued at a variety of spatial and temporal scales. Need for multiscale and cross-scale analyses; Multiscale conducts the assessment at two or more separate scales. Cross-scale analysis conducts a multiscale assessment studying cross-scale interactions.

Value pluralism aim for an inclusive approach to represent the diversity of the values held by different stakeholders, throughout diverse valuation approaches and methods (Martín-López et al. 2014, Díaz et al. 2015, Jacobs et al. 2016)
Does the article analyze the power relations between the actors?

Identification of conflicts and trade-offs within coastal ES

Does the article analyze the prioritization of values and interests?

Does the article analyze actors' access to the benefits of coasta ES?

\section{Spatial scale}

Time frame
Are multiscale analyses
performed?
Are cross-scale analyses
performed?
Types of valuation

Types of valuation

Methodology for coastal ES valuation

Does the paper assess uncertainty?
Yes; No

E.g., negative impacts of energy production on aesthetics; negative impacts of aquaculture on coastal protection Yes; No

E.g., large fishing companies vs. small fishing companies; private access vs. public access, social groups that benefit from coastal protection vs. social groups that deal with negative effects

Local as social or ecological community. Regional as part of a country with similar social or ecological features.

National as national borders. Supra-regional as part of the world with similar social or ecological features.

Supranational as more than one country. Global as world.

Long term (+1 year). Medium term (-1 year). Short term (1 month or less)

Yes; No

Yes; No

Monetary, environmental, and sociocultural values classification, based on Gómez-Baggethun et al. (2014). Monetary as assessments using money as a measurement unit. Environmental as assessment of ecological function, processes, and components for ES, also assessment of inherent value of biodiversity and ecosystems. Sociocultural as nonmonetary methods to assess spiritual enrichment, cognitive effects, recreation, aesthetic experience, and people's preferences regarding ecosystem service.

E.g., hedonic pricing, indicators, travel cost method

Yes; No

\begin{abstract}
Uncertainty "as any departure from the unachievable ideal of complete determinism" (Walker et al. 2003:8). Funtowicz and Ravetz (1990) state that uncertainty is driven from inadequate information for three different reasons: inexactness, unreliability, and border with ignorance (Funtowicz and Ravetz 1990). Nevertheless, new knowledge might either reduce or raise uncertainty, as in complex processes it can expose unknown or hidden uncertainties (Walker et al. 2003, Walker and Haasnoot 2011).
\end{abstract}

Types of uncertainty

Which needs and satisfiers of human well-being are considered?
HWB is sustained by the accomplishment of fundamental human needs (Max-Neef et al. 1998).
Human well-being (HWB)
Technical as state of affairs in which possible outcomes are known and the probabilities associated to such results can be calculated (Kovacic 2015). Methodological as imperfection of valuation methods used for coastal ES assessments. Epistemological as imperfection of our knowledge (Walker et al. 2003). Ontological as the inherent variability and complexity of social-ecological systems (Walker et al. 2003).

Max-Neef et al. (1998) matrix of human needs. Nine axiological human needs, subsistence, protection, affection, understanding, participation, idleness, creation, identity and freedom, and four existential categories of human needs, being (qualities), having (things), doing (actions), and interacting (settings). including participatory approaches and upward efforts for ES mapping.

The above-mentioned changes open coastal ES research up to multidisciplinary and interdisciplinary research, embracing manifold scientific disciplines, particularly social sciences, and new methodologies. These have been fundamental changes in the study of the social-ecological complexity of coastal ES. However, the results prove that, largely, coastal ES research has yet to capture coastal social-ecological complexity, especially the role and interactions of non-natural components and the links between ES and HWB.

\section{Integration of social and ecological components}

The analysis of the cascade-model categories for the articles reviewed demonstrates that, generally, assessments of coastal ES focus their attention on capacity and value, while flow and benefit received less attention. Consequently, value and capacity are the most common aspects of provisioning services; this is the case of food provision (fishing and increasingly also aquaculture) or 
biotic materials (mangrove wood). In the case of regulating and maintenance services, the articles target the capacity assessment and values of, especially, water purification, climate regulation, life cycle maintenance, and coastal protection. Within cultural services, the value part of the cascade model is the focal point, most commonly for recreational services. Other cultural services, such as cognitive effects, aesthetic values, and symbolic services are also addressed through the value category. Therefore, in this review, the main gaps identified regarding ES cascade model components are capacity for provisioning and cultural services and the flow and benefit of provisioning, regulating and maintenance, and cultural services.

Demand is another missing aspect in scientific papers on coastal ES, (considered only in 3\% of the papers analyzed). Capacity, flow, and demand assessments are needed in order to understand (un)sustainable uptake and (un)satisfied demand (Geijzendorffer et al. 2015, Wei et al. 2017). Nonetheless, the links between capacity, flow, and demand are also dynamic and complex. (Un) sustainable uptake and (un)satisfied demand can be modified through technology (Rieb et al. 2017), or forms of social organization (Wei et al. 2017), hence through dynamic loops of coproduction.

\section{Coproduction}

The reviewed articles did not completely embrace the complex and dynamic loops of coproduction. First, the temporal perspective, highly relevant in coproduction processes, is included only in some of the papers, mainly through medium-term scales, and exceptionally, through short-term and long-term scales. In many cases, it refers solely to temporal evaluation of the ecological status for specific ecosystems and the link to coastal ES capacity, i.e., the links between the ecological integrity of fisheries for food provision, or wetlands and salt marshes for water purification, or mangroves and other biotic structures for coastal protection, or nursery habitats for life cycle maintenance or marine biodiversity for recreational services. However, the functional link between ecological integrity and ES capacity is not entirely understood because of ecological complexity and lack of data, especially in the case of marine ecosystems (Liquete et al. 2013, Maes et al. 2013) Furthermore, these papers assess the ecological integrity of coastal ecosystems, but overlook the interplay with social components. Second, there are papers that do take into consideration coproduction by social-ecological interaction. In this regard, a common approach is the study of land-use evolution, as an illustration of social components, and the effects on ES capacity. Some examples are changes in land and use in mangrove forests and ES capacity for wood production, or landuse evolution in wetlands or salt marshes and water purification capacity. Again, there is a gap in knowledge regarding the link between land use and ES provision, i.e., the functional relationships between land use and ES are still imprecise (Maes et al. 2013). In addition, this approach reduces the complexity of social-ecological systems because land use is one of the multiple expressions of social-ecological systems, rather than a static one. Moreover, the papers describe changes in land use, but none provides an analysis of the social-ecological processes behind these changes. Very few papers consider socioeconomic aspects, such as demographic trends or economic growth, as factors of coproduction. Thus, the reviewed papers apply a descriptive approach rather than an analytical one. Third, other papers have aimed to integrate coproduction by studying the relationships between human impacts (overfishing, nutrient inputs, global warming) on coastal ES, such as articles applying the DPSIR (drivers, pressures, state, impact, and response) framework. These papers partly integrate the complexity of coproduction, as they reduce social-ecological complexity to linear causal relations (Gari et al. 2015). Fourth, fundamental aspects of coproduction such as the role of institutions and governance systems, knowledge, technology, socio-historical legacies, man-made structures, and nonmaterial interactions (Reyers et al. 2013, Felipe-Lucía et al. 2015, Fischer and Eastwood 2016, Palomo et al. 2016) are not commonly embraced in the reviewed papers. The link between institutions and governance systems and coastal ES is rather unexplored; some papers describe existing legislative context but without accounting for its relations to coproduction. Another often unexplored aspect is the role that man-made structures play. Man-made structures, such as waterfronts, harbors, dikes, breakwaters, wind energy farms, and artificial reefs, provide coastal ES, but at the same time replace previously existing natural structures that also provided coastal ES (Garcia Rodrigues et al. 2017). Likewise, the roles of technology or knowledge in coproduction are not assessed either, such as value and value preference. Last, regarding the effects of sociohistorical legacies, the reviewed papers did not seek to understand how past choices create path dependencies for the contemporary context.

\section{Institutions and governance}

Institutions and governance are not central elements of coastal ecosystem assessments. Nevertheless, some papers aim to include institutions and governance from a legislative perspective, explaining principal policies and policy bodies, although without studying the relations with coastal ES capacity, flow, or benefit. The links between ES and institutional arrangements and governance systems are poorly understood. Only a few papers identify and analyze actors, their institutional arrangements (formal and informal), their conflicts, and decision-making processes. However, the literature reviewed does not assess how institutional arrangements and governance structures shape coastal ES supply, delivery, use, and access, as the conflicts between informal and formal institutional arrangements (informal agreements between coastal local communities defining spatial borders over fishing areas, formal agreements between governance structures limiting fishing activities over certain areas without considering local communities' agreements). Coastal ES frameworks acknowledge the relevance of governance and institutions; however, this is not translated into ES assessments. ES assessments need more guidance and effort to link governance and institutions to ES. Although the link is still unclear, several articles (30), make policy recommendations.

\section{Trade-offs and power}

Trade-offs are frequently cited in coastal ES literature, such as those between food provision and water purification in wetlands, or biotic material and coastal protection in mangroves, or recreation and tourism and life cycle maintenance. The identification of trade-offs and the actors involved are increasingly more common in the reviewed coastal ES literature, but their assessment is less frequent. Hence, although an increasing number of papers identify trade-offs and the actors involved, they do not analyze them. Furthermore, in some cases, 
the approach concerns conflicts regarding ecosystem use, rather than trade-offs within coastal ecosystem services. The most common example of conflicts regarding ecosystem use is aquaculture versus other traditional uses of mangroves. The papers also identify conflicting situations between anthropic impacts on coastal ecosystems and coastal ES, for example, how the urbanization of dunes obstructs coastal protection and life cycle maintenance services. Similar to trade-offs, actors are identified but the conflicts are not actually analyzed.

Although trade-offs and conflicts are acknowledged and mentioned, very few case studies assess them or, consequently, aim to understand the forces and dynamics behind them. As a result, few papers study power relations between actors and how they affect coastal ES, access to them, benefit distribution, and value prioritization.

\section{Temporal and spatial scales}

Time and space are other overlooked aspects in terms of scale in the reviewed papers. The manuscripts typically locate the analysis on one singe spatial scale, particularly local and regional scales, and to a lesser extent, the national, supra-regional and in some cases global scales. However, there has been very little work that has combined different spatial scales, thereby understanding the spatial differences and trans-scalar interactions of coastal ES. Multiscale and cross-scale assessments are not common, only a few examples can be found for services such as climate regulation, coastal regulation, and food provision, which consider the local and regional scale in their assessments, but do not assess the interaction between the different scales. In terms of temporal scale, the articles also locate the analysis on one single scale, particularly medium-term, with very few exceptions focusing on short and long term and multiscale assessment for regulating services.

The review also recognized a relevant gap regarding spatial and temporal issues of coastal ES, as the temporal and spatial pathways of coastal ES are barely studied; coastal ES, capacity, flow, and demand might have different spatial locations and time frames. Local demand for ES is sometimes met by ES being provided in distant places (Rieb et al. 2017), yet the coastal communities might bear the costs of distant benefits in time and space, e.g., the air purifications service provided by mangroves through carbon sequestration is produced locally or regionally but delivered globally.

\section{Value pluralism}

Monetary and environmental valuations are the most common type (Fig. 2). However, the results demonstrate an increase in socio-cultural value assessments since 2012 (Fig. 2), particularly for cultural services in the form of rankings. Value assessment of provision services is mostly featured by defining monetary values and methods: market values of fisheries and aquaculture products, jobs, and income provided by fishing and aquaculture activities, the market price of mangrove wood, employment and income created by wood extraction, or costs of water consumption and irrigation. Ecological valuations are also relevant, especially for food provisioning as a means to study biophysical processes and ecological functions that support service provision. Very few articles have studied the socio-cultural values of these services (the few exceptions to this assess actors' preferences and social values regarding fishing and mangrove exploitation).
In the case of regulating and maintenance services, monetary, particularly, and environmental valuations are again the most common assessments of services such as water purification, morphodynamic coastal regulation, climate regulation, and life cycle maintenance. In the case of monetary valuations, this focuses on avoided costs of property damage and the market value of carbon. Furthermore, in some cases there is confusion between the value of the regulating service and the support or benefit for other services or activities. For example, water purification is in many cases valued as a benefit or cost for fishing, or even life cycle maintenance services are valued as a means for supporting recreation. Socio-cultural valuations are less commonly applied, although there are some exceptions regarding actors' preferences for coastal protection and life cycle maintenance. For example, some papers aim to assess the recreational and aesthetic values of marine biodiversity.

The most common valuations of cultural services are monetary and socio-cultural. For recreation services, monetary valuations are more common (economic value, income, jobs) than sociocultural valuations. However, socio-cultural values are also considered, such as perceived benefits and preferences by practitioners of tourism and recreation. Similar aesthetic services are valued in monetary terms, typically sea views and coastal landscape beauty. Nevertheless, the socio-cultural values of aesthetic services are also considered, for example by assessing the public preferences and social perceptions of beach users. Cognitive effects are also assessed by monetary and socio-cultural values, commonly evaluated through the monetary value of research (e.g., financial expenditure, research funds), social perception, and valuation of education and cognitive processes (e.g., perceived benefit for education). Likewise, very few papers explore the socio-cultural values of symbolic services such as spiritual, religious, and social relations, cultural heritage, or sense of place.

Sociocultural valuations are established by ranking methods to study stakeholders' priorities concerning coastal ES. Stakeholders individually or collectively express their preferences and perceptions on coastal ES via surveys, interviews, focus groups, or other participatory methods. It was noted that the most common method of socio-cultural valuations is surveys, which is not an open and inclusive method because answers are highly restricted and might be subject to the values and perceptions of the researchers. In addition, results have proven that the most questioned actors are politicians and experts, as well as recreational users and tourists in the case of recreation-service valuations. Therefore, local stakeholders and communities are commonly excluded from such rankings.

\section{Uncertainty}

The revised literature makes occasional reference to uncertainty. However, in many such cases it is not assessed or quantified, except for technical uncertainty, i.e., quantification error, which usually does carry out this assessment or quantification. In some cases, methodological uncertainty is discussed. Specifically, papers discussing this are concerned with methods for the economic and cultural assessment of coastal ES, ecological assessment of regulating services in marine ecosystems, mapping coastal ES, and the temporal dynamics of coastal ES. In these cases, uncertainty is acknowledged but generally not assessed. 
Fig. 2. The results of this systematic review are presented in this infographic figure. The top part of the figure presents the percentage of articles assessing demand, coproduction processes, institutions and governance, trade-offs and power, multiscale (temporal and spatial) processes, and uncertainty. The central-right pie graph represents the number of manuscripts that address each human well-being (HWB) axiological need defined by Max-Neef et al. (1998): subsistence, protection, recreation, understanding, identity, creation, freedom, participation, and affection. On the other side of the figure (central left-side), the column graph represents how many articles address each of the cascade-model components (capacity, flow, benefit, and value) by ecosystem services (ES) general categories (provision, regulating and maintenance, and cultural). Finally, the graph located on the lower part of the figure shows the number of articles and type of assessed values per year, from 1998 to 2017.
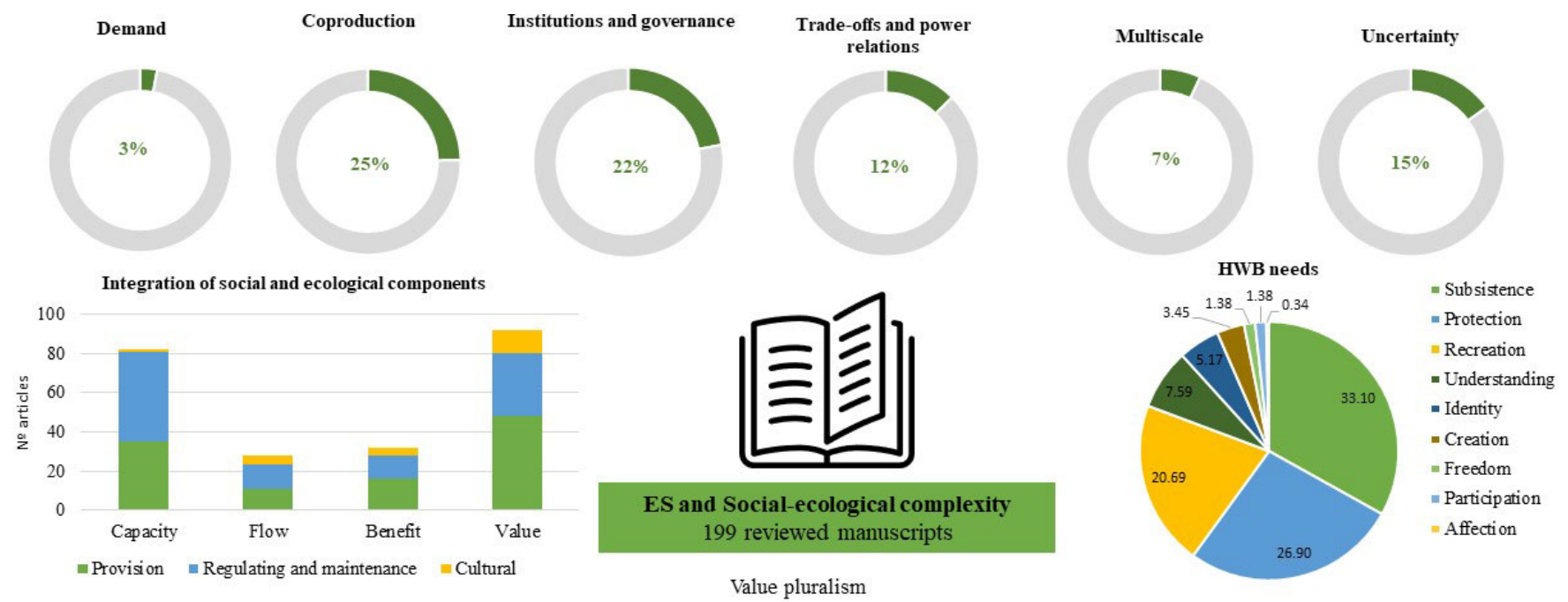

$\approx$ Provision $=$ Regulating and maintenance $=$ Cultural

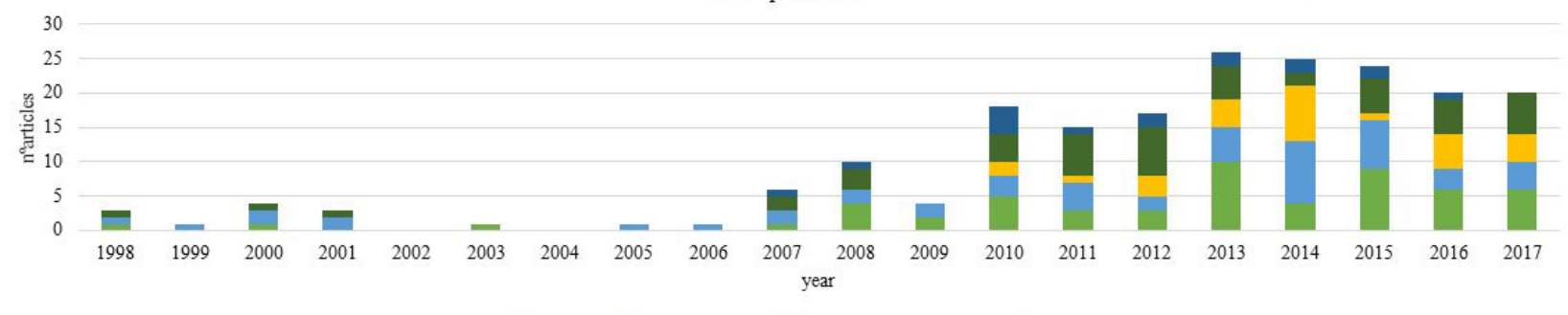

$\varpi$ Monetary $=$ Environmental $\|$ Socio-cultural $\|$ Mixed $=\mathrm{N} / \mathrm{A}$

Epistemological and ontological uncertainty is mentioned only very exceptionally. Manuscripts also refer to epistemological uncertainty in terms of the lack of knowledge regarding ecological, and to a lesser extent, complex social processes such as synergies, spatial and temporal dynamics, and value preference. The aforementioned uncertainty could also be ontological because a greater effort to create new knowledge might not reduce uncertainty, but rather increase it. Complex SES systems are characterized by an inherent ontological uncertainty (Biggs et al. 2015) because of their own complexity and variability, which is not analyzed in the reviewed manuscripts. Very few articles have considered or assessed the inherent uncertainty of socialecological complexity, apart from some exceptional cases that cite the complexity of cultural services.

Results show that many papers discussing uncertainty use or conceptualize participation as a method to approach this. Uncertainty is also a fundamental factor in decision making (Walker et al. 2003, Chisholm and Wintle 2012, Schlüter et al. 2012, Biggs et al. 2015).

\section{Human well-being}

Few articles have explicitly studied the role of SES complexity in ES and HWB links, namely how complex SES processes determine HWB through access, social and individual conceptions of well-being, and spatial and temporal context. HWB and ES linkages need to be further studied in assessments of coastal ES, such as how different social groups conceptualize HWB and satisfy their HWB needs in coastal areas.

By using the Max-Neef matrix (Max-Neef et al. 1998), this review has identified the needs and satisfiers that are most commonly addressed by the reviewed articles, those that refer to having material aspects related to subsistence, protection, and recreation, such as food, work, dwelling, and recreation (Fig. 2). The papers also mention interacting needs for subsistence, protection, and recreation by addressing, from a materialistic perspective, satisfiers such as living space, dwelling, seascape, and coastal landscapes. Contrarily, nonmaterial aspects of subsistence, protection and recreation are not commonly addressed. In terms of subsistence, a fundamentally missing $\mathrm{HWB}$ aspect is adaptability. Humans need to develop adaptability and resilience to frequent and unexpected changes, especially taking into 
account the social-ecological complexity and effects of climate change on coastal areas. Other fundamental but rather unexplored HWB dimensions of subsistence needs are physical and mental health and social setting. Social setting is also unexplored, but essential because humans do not live as isolated individuals, but in socially interacting communities.

The protection of coastal areas is especially relevant for HWB. Although coastal areas are particularly vulnerable and affected by natural hazards, some strategic satisfiers are missing from the reviewed analysis: adaptability, insurance systems, cooperation, and planning. Protection from hazards requires adaptability, insurance systems, and the rights of those affected, and the need for cooperation, planning, and help to cope with natural hazards. Similarly, recreation has become a key issue on coastal areas because they are central spaces of recreation and leisure. The studied coastal ES literature has focused its attention on material satisfiers. However, the important dimensions of leisure and recreation are not only material, but also non-material such as curiosity, lack of worry, tranquility, privacy, for example, the curiosity experienced by discovering new coastal cultural services, such as landscapes, or the tranquility that might be experienced on a peaceful beach. The above-mentioned aspects of HWB are frequently unexplored issues.

Furthermore, a remarkable gap regarding HWB is the absence of assessment of the needs of understanding, participation, creation, identity, affection, and freedom (Fig. 2). Even when these needs are researched, it is mostly to refer to material aspects of HWB. Understanding needs are approached through countable satisfiers (educational policies, schools, and universities), while omitting being and doing from individual and collective cognitive processes (critical conscience, receptiveness, study), and omitting informal spaces for understanding (groups, communities, family). Participation needs and satisfiers are also rarely considered in scientific literature on coastal ES, although some exceptions are found. These articles mention having rights and responsibilities, or the integration of actors in organizations.

The literature on coastal ES proposes a somewhat restricted view of this by solely referring to creation through having skills and work, while other satisfiers are excluded, such as imagination or inventiveness. Likewise, the reviewed literature provides a partial vision of identity. It discusses identity components, such as symbols, language, religions, and values. But some of the satisfiers that were found to be missing are related to acknowledging identity, such as sense of belonging, or differentiation. Finally, the revised scientific literature did not address the needs for affection and freedom. Affection refers to social bonding and cooperation, which are important within coastal spaces as multiple actors and social relations are at stake. Furthermore, freedom features such as autonomy and temporal/spatial plasticity are also significant but ignored satisfiers. Autonomy is a fundamental satisfier for coastal communities because they must be able to control decision making and management. Temporal and spatial plasticity is expressly relevant for coastal communities because coastal social-ecological systems are highly reliant on temporal and spatial dynamics. Freedom and its satisfiers should not only be considered a means for coastal management, but also as individual and collective ends in themselves. Actors might hold different values and preferences, which may be conflicting, but all of them must have the freedom to defend what they stand for.

The review has also shown that satisfiers identified in the literature are generally material, whereas nonmaterial satisfiers are overlooked. Logically, material satisfiers, such as food, may be considered vital for human subsistence. Coastal management and coastal ES literature have been characterized by addressing humans and their well-being as uniform elements. They have commonly been approached from materialistic perspectives, rather than from the more inclusive alternatives of human needs and dimensions of well-being. Thus, important gaps are still present in the literature that hinder the basic understanding needed for sustainability.

\section{DISCUSSION}

This literature review has identified important gaps in coastal ES research. First, the lack of integration with regard to ecological and social components, particularly the analysis of cascademodel components, shows that flow and demand are significantly missing components. Second, a partial understanding of coproduction as fundamental aspects of coproduction is not embraced (institutions and governance systems, knowledge, socio-historical legacies, social representations, technology, and infrastructures). Third, manuscripts did not study how power underpins coproduction, trade-offs, and access and distribution of ecosystem service benefits. Fourth, there is a lack of assessments that combine different scales, such as multiscale and cross-scale assessments. Fifth, there is a gap in the literature concerning the intrinsic and relational dimensions of HWB, such as an understanding of HWB distribution among social groups. Sixth and finally, uncertainty is a missing aspect in coastal ES assessments, and receives only partial and superficial treatment in coastal ES research.

It is beyond the scope of this manuscript to study whether these gaps exist in more general ES literature. Nevertheless, we found a number of contradictions and similarities with previous general ES literature reviews and critical reflective manuscripts ${ }^{[2]}$. Similar to coastal ES research, ES assessments have focused on economic valuation and the ecological assessment of the capacity of ecosystems (Seppelt et al. 2011, Wei et al. 2017), while flow and especially demand have been misrepresented. Nevertheless, in recent years, some authors have been working on ES capacity and flow models that seek to define the spatial distribution and assessment of capacity, flow, and demand (such as, Kroll et al. 2012, Villamagna et al. 2013, Burkhard et al. 2014, Geijzendorffer et al. 2015, Baró et al. 2016). ES coproduction still remains unclear (Bennett et al. 2015); to the authors' knowledge, coproduction is a rather unexplored aspect of ES, although frameworks such as the MEA and IPBES explicitly acknowledge the role of humans in the coproduction of ES. Some papers explore the issue of coproduction by recognizing how different social aspects (institutions, governance systems, social representations and values, technology and infrastructure, labor, financial capital, and power relations) are linked to ES delivery. Such papers include those by Ernstson (2013), Spangenberg et al. (2014), Huntsinger and Oviedo (2014), Farhad et al. (2015), Felipe-Lucía et al. (2015), Fischer and Eastwood (2016), Palomo et al. (2016), BerbésBlázquezet al. (2017), Outeiro et al. (2017). Power is also an aspect that is left aside within ES literature (Felipe-Lucía et al. 2015, 
Berbés-Blázquez et al. 2016), which has not paid attention to the role that power plays in the coproduction of ES and in its benefits and cost distribution across social groups. The literature review conducted by Hamel and Bryant (2017) shows that uncertainty has also been approached both superficially and partially.

Unlike ES coastal research, ES research increasingly acknowledges different scales (Schröter et al. 2018); a growing body of literature focuses on the spatial linkages between providing to benefiting areas (such as Kroll et al. 2012, Bagstad et al. 2013, García-Nieto et al. 2013, Serna-Chavez et al. 2014, Schröter et al. 2018). This body of literature conceptualizes and quantifies flow as the spatial movement of material, energy, and information from the location that supplies ES to the location where benefits are enjoyed (Bagstad et al. 2013, Schröter et al. 2018). Such conceptualization serves to understand distributional spatial patterns and trade-offs. Nevertheless, temporal scales are rarely embraced.

In ES research there is a growing body of academic work on value pluralism and disaggregate analysis, although ecosystem-service research still fails to consider both aspects (Dawson and Martin 2015). Several authors, such as Dendoncker et al. (2013, 2018), Iniesta-Arandia et al. (2014), Martín-López et al. (2014), Jacobs et al. (2016), have made great efforts to develop and apply value pluralism. Additionally, relevant global science-policy interface initiatives such as the IPBES are embracing and supporting value pluralism ES in valuations (Jacobs et al. 2018). Another growing research field is the disaggregated analysis of HWB among social groups, by authors such as Daw et al. $(2011,2016)$, Bennett et al. (2015), Dawson and Martin (2015), Horcea-Milcu et al. (2016), Chaudhary et al. (2018), Hossain et al. (2017), Villamagna et al. (2017), and initiatives such as IPBES and Ecosystem Services for Poverty Alleviation (ESPA).

Despite these efforts, the social dimension is still misrepresented in ES assessments. The lack of integration of social science in ES and in environmental interdisciplinary research is very well analyzed by several authors (Norgaard 2010, Mooney et al. 2013, Castree et al. 2014, Stojanovic et al. 2016, Stenseke and Larigauderie 2018). The integration between environmental and social science has proved to be challenging (Mooney et al. 2013, Milanez 2015, Stojanovic et al. 2016, Barthel and Seidl 2017) because these areas may have different and even opposing philosophical approaches; a differing use of the same or similar terminologies; existing uncertainties within present fields of knowledge; and different social and political positions of research. On this subject, Stojanovic et al. (2016) question whether all social science aspects can be approached under a general systems framework. System theory embraces complexity and provides a holistic framework. However, the social sciences are critical of the system conceptualization of certain aspects of society because this simplifies and undertheorizes social objects and processes (Stojanovic et al. 2016). Furthermore, certain authors have also stressed the issue of "the hegemony of natural science," whose disciplines tend to be more valued than the social sciences (Ledford 2015). Consequently, the social sciences are dismissed and social and environmental integration is asymmetrical in terms of power, funding, personnel, knowledge production, and independence (Viseu 2015).

Social misrepresentation is even more aggravated in coastal ES research. An important reason behind coastal ES gaps is the fact that marine and coastal research on ecosystem services have lagged behind terrestrial ES research (Barbier 2012, Liquete et al. 2013, Portman 2013) corresponding to a knowledge gap on marine ecosystems (see Norse and Crowder 2005). Nevertheless, since MEA of 2005 added ES marine, ES research has been supported, but as a separate body of literature to that of terrestrial ES (Portman 2013). Consequently, the coastal, as a single landscape unit, has received little attention (Portman 2013). Land and sea systems are inextricably linked by flows of materials, energy, and knowledge. Some coastal animals and plants spend their life between the land and the sea (Portman 2013). ES research needs to consider coastal areas as a single unit of analysis at multiple temporal and spatial scales.

In addition to the above-mentioned aspects, the lack of social dimension in noncoastal and coastal ES research also responds to the dominance of ecologically oriented scientists and economists, i.e., through a revision of the most influential authors (Kull et al. 2015), identifying a network of researchers from the subfields ecological economics, systems ecology, and conservation biology. The ES concept has been built on the consensus among those disciplines on how to approach society and environment relationships, while not including other perspectives. This consensus is not impartial because ES is a political concept. Behind scientific objectivity, ES actually reflects specific ideas, values, power relations, and political-economic structures, which enable certain interventions and debates (Kull et al. 2015). The issue is, then, what interventions and debates do we want to support as scientists? In our opinion, coastal and noncoastal ES research should be informing the debates that societies face for resource management; who has or who controls access? Who are the winners and losers? What are the trade-offs?

To this end we argue that current coastal ES literature needs to embrace social-ecological complexity and overcome the existing fragmentation of knowledge, which comes mostly from ecological and economic disciplines. To do so, we suggest five fundamental aspects to consider. First, coastal ES research should pay special attention to flows, studying the spatial and temporal pathways from ES production areas to demand or benefiting areas at different temporal and spatial scales. In this way, all cascade-model components could be covered, and multiscale and cross-scale processes could be understood. Such information leads to more research on trade-offs and hence benefit and cost distribution. The tools and frames have already been developed by authors such as Bagstad et al. (2013) and Schröter et al. (2018). Second, the study of ES flows should be accompanied by coproduction assessment - Palomo et al. (2016) suggested a possible framework - as a means to understand natural and non-natural components that coproduce the ES along the flow pathway. Third, power should be included within ES analysis, i.e., how power mediates coproduction processes and benefit distribution. With such knowledge it will be possible to identify and understand the access or control of access of ecosystems services and their derived benefits, hence when, where, by who, and how ecosystem service benefits are accessed. Fourth, all dimensions of HWB should be considered. In free and open spaces, participation stakeholders could express their values, and trade-offs and conflicts would be exposed. Fifth, uncertainty needs to be evaluated and communicated to stakeholders. Uncertainty assessments are relevant to decision making because their results might shape a decision, but also they increase transparency and understanding of the issue at stake 
Fig. 3. Conceptual framework that integrates the gaps identified during the review. The framework outlines coproduction and power relations as the core factors of assessments of coastal ecosystem services (ES). Relations of cascade-model components are bidirectional, not unidirectional. Cascade-model components are affected by human drivers of change (drivers that result from human decisions and interactions, such as institutions and governance, technology, market dynamics, etc.) and nonhuman drivers of change (drivers originated by natural dynamics, outside human control, such as natural climate phenomena). Note the mutual influence between human drivers of change, on the one hand, and institutions, governance, and other coproduction assets, on the other. ES services are not a free gift of nature, but are instead coproduced by human inputs. Although not all ES are coproduced equally, given that human contributions to ES might vary along the stages of ES production (Reyers et al. 2013, Guerry et al. 2015, Fischer and Eastwood 2016, Palomo et al. 2016, Outeiro et al. 2017). Power relations underpin access to ES, distribution of benefits, and definition and preference of values. All above-mentioned processes take place at different temporal and spatial scales and through interactions and feedback processes that operate at many scales. This complexity leads to high levels of uncertainty.

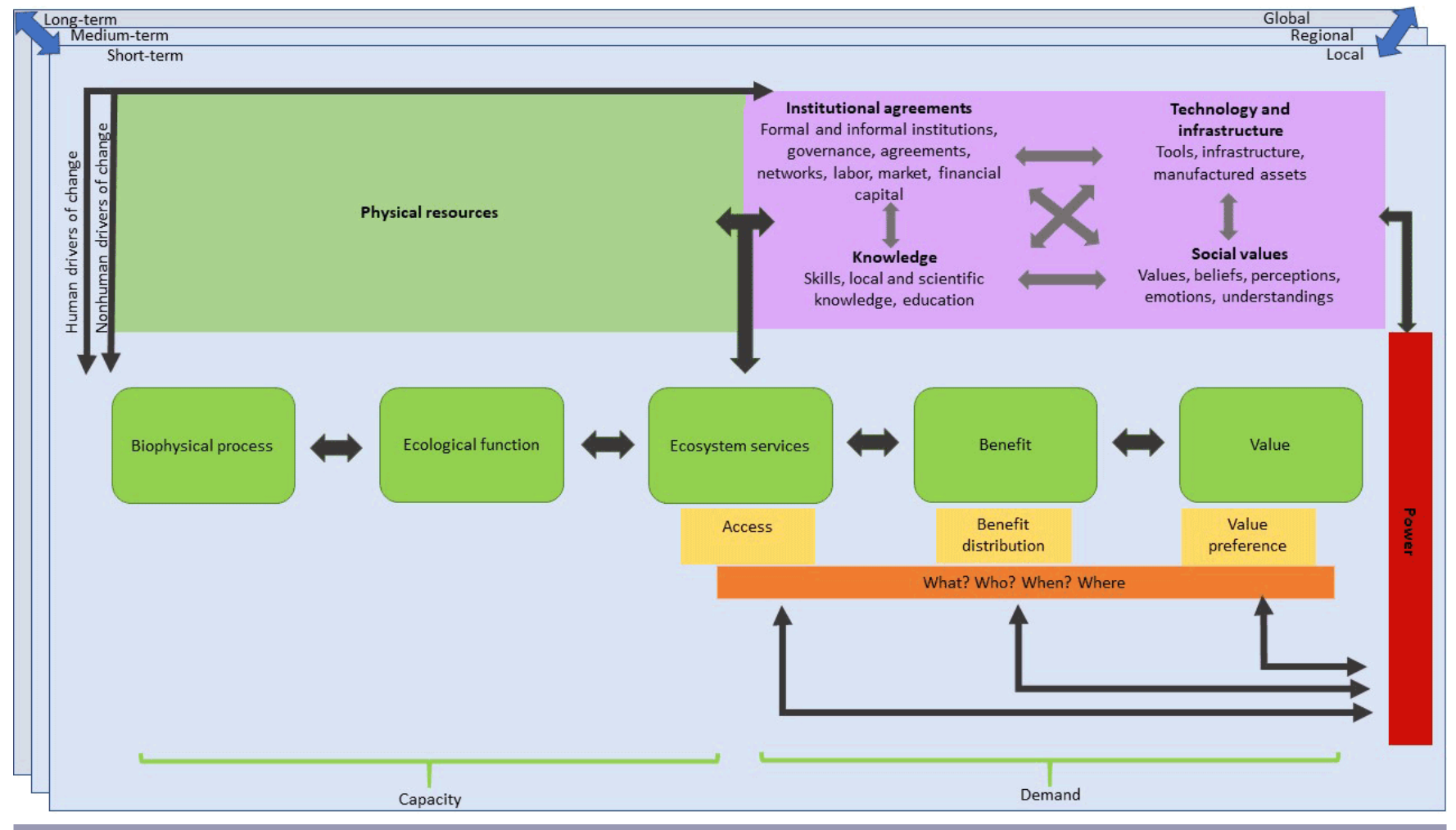

(Pappenberger and Beven 2006, Hamel and Bryant 2017). Including uncertainty in decision making should also be considered a fundamental right because decision makers and stakeholders involved have the right to know all knowledge limitations in order to make up their own minds (Pappenberger and Beven 2006, Hamel and Bryant 2017).

We propose a conceptual framework (Fig. 3) that integrates the five above-mentioned aspects: ES flows, coproduction, power relations, temporal and spatial scales, value pluralism, and uncertainty. Our main contribution to the existing literature on coastal ES is to go further than the linear-cyclical approach of general ES frameworks by focusing on coproduction and power, as means to understand the assemblage of complex and nonlinear interactions and feedback processes of coastal ES production, supply, demand, and use processes, i.e., sorting out socialecological relations and feedback loops enabling ES processes. The suggested framework is not solely an analytical tool, but is also a normative tool because it also seeks to guide coastal management debates and interventions toward environmental and social justice issues: control, access, trade-offs, benefit, and cost distribution, i.e., winners and losers. Nevertheless, each coastal ES study has different needs and objectives, which might not fully cover all the elements and relations described in the framework.

${ }^{\text {[1] }}$ ( TITLE-ABS-KEY ( "ecosystem service" OR "environmental service") AND TITLE-ABS-KEY ( "coastal” OR "litoral” OR "littoral")) AND ("mangroves" OR "wetlands" OR "coral reefs" OR "litoral forest" OR "beach" OR "dunes" OR "saltmarshes" OR "seagrass" OR "littoral sedmiment" OR "coastal shores" OR "cliffs" OR "coastal mudflat" OR "machair" OR "sandy shore" OR "ledges and shores" OR "coastal lagoons" OR "Littoral rock" OR "sublittoral rock" OR "sublittoral sediment" ) AND ( "provisioning" OR "supporting" OR "regulating" OR "regulation and maintenance" OR "cultural" ) AND ( EXCLUDE ( PUBYEAR , 2018 ) ) AND ( EXCLUDE ( DOCTYPE, “ip”) OR EXCLUDE ( DOCTYPE, "bk”) OR 
EXCLUDE ( DOCTYPE, "no") ) AND ( EXCLUDE ( LANGUAGE, "Chinese") OR EXCLUDE ( LANGUAGE, "Spanish") OR EXCLUDE ( LANGUAGE , "German")).

${ }^{[2]}$ Some exisitng general ES literature reviews: Seppelt et al. (2011), Martínez-Harms and Balvanera (2012), Summers et al. (2012), Portman 2013, Bennett et al. 2015, Costanza et al. 2017, Hamel and Bryant 2017, Rieb et al. 2017, Wei et al. 2017.

Responses to this article can be read online at: http://www.ecologyandsociety.org/issues/responses. $\mathrm{php} / 10883$

\section{Acknowledgments:}

This research was carried out under the framework of POLICLIMA project (CSO2016-76842-C2-1-R). The first author was supported by a PhD grant (FI-2017) from the Agència de Gestió d'Ajuts Universitaris. The second author was supported by Ramón y Cajal contract (RYC-2013-13392) from the Ministerio de Economía $y$ Competitividad.

\section{LITERATURE CITED}

Adams, H., W. N. Adger, S. Ahmad, A. Ahmed, D. Begum, A. N. Lázár, Z. Matthews, M. M. Rahman, and P. K. Streatfield. 2016. Spatial and temporal dynamics of multidimensional well-being, livelihoods and ecosystem services in coastal Bangladesh. Scientific Data 3:160094. https://doi.org/10.1038/sdata.2016.94

Ariza, E., F. Pons, and F. Breton. 2016. Is "socio-ecological culture" really being taken into account to manage conflicts in the coastal zone? Inputs from Spanish Mediterranean beaches. Ocean and Coastal Management 134:183-193. https://doi. org/10.1016/j.ocecoaman.2016.10.006

Bagstad, K. J., G. W. Johnson, B. Voigt, and F. Villa. 2013. Spatial dynamics of ecosystem service flows: a comprehensive approach to quantifying actual services. Ecosystem Services 4:117-125. https://doi.org/10.1016/j.ecoser.2012.07.012

Baral, H., M. R. Guariguata, and R. J. Keenan. 2016. A proposed framework for assessing ecosystem goods and services from planted forests. Ecosystem Services 22:260-268. https://doi. org/10.1016/j.ecoser.2016.10.002

Barbier, E. B. 2012. Progress and challenges in valuing coastal and marine ecosystem services. Review of Environmental Economics and Policy 6(1):1-19. https://doi.org/10.1093/reep/ $\underline{\operatorname{rer} 017}$

Baró, F., I. Palomo, G. Zulian, P. Vizcaino, D. Haase, and E. Gómez-Baggethun. 2016. Mapping ecosystem service capacity, flow and demand for landscape and urban planning: a case study in the Barcelona metropolitan region. Land Use Policy 57:405-417. https://doi.org/10.1016/j.landusepol.2016.06.006

Barthel, R., and R. Seidl. 2017. Interdisciplinary collaboration between natural and social sciences - status and trends exemplified in groundwater research. PLOS ONE 12(1):e0170754. https://doi. org/10.1371/journal.pone.0170754

Bennett, E. M., W. Cramer, A. Begossi, G. Cundill, S. Díaz, B. N. Egoh, I. R. Geijzendorffer, C. B. Krug, S. Lavorel, E. Lazos, L.
Lebel, B. Martín-López, P. Meyfroidt, H. A. Mooney, J. L. Nel, U. Pascual, K. Payet, N. P. Harguindeguy, G. D. Peterson, A. H. Prieur-Richard, B. Reyers, P. Roebeling, R. Seppelt, M. Solan, P. Tschakert, T. Tscharntke, B. L. Turner, P. H. Verburg, E. F. Viglizzo, P. C. L. White, and G. Woodward. 2015. Linking biodiversity, ecosystem services, and human well-being: three challenges for designing research for sustainability. Current Opinion in Environmental Sustainability 14:76-85. https://doi. org/10.1016/j.cosust.2015.03.007

Berbés-Blázquez, M., M. J. Bunch, P. R. Mulvihill, G. D. Peterson, and B. van Wendel de Joode. 2017. Understanding how access shapes the transformation of ecosystem services to human wellbeing with an example from Costa Rica. Ecosystem Services 28:320-327. https://doi.org/10.1016/j.ecoser.2017.09.010

Berbés-Blázquez, M., J. A. González, and U. Pascual. 2016. Towards an ecosystem services approach that addresses social power relations. Current Opinion in Environmental Sustainability 19:134-143. https://doi.org/10.1016/i.cosust.2016.02.003

Biggs, R., C. Rhode, S. Archibald, L. M. Kunene, S. S. Mutanga, N. Nkuna, P. O. Ocholla, and L. J. Phadima. 2015. Strategies for managing complex social-ecological systems in the face of uncertainty: examples from South Africa and beyond. Ecology and Society 20(1):52. https://doi.org/10.5751/ES-07380-200152

Bremer, S. R. 2011. Exploring a 'post-normal' science-policy interface for integrated coastal management. Thesis. Massey University, Palmerston North, New Zealand.

Burkhard, B., M. Kandziora, Y. Hou, and F. Müller. 2014. Ecosystem service potentials, flows and demands-concepts for spatial localisation, indication and quantification. Landscape Online 34:1-32. https://doi.org/10.3097/LO.201434

Butler, C. D., and W. Oluoch-Kosura. 2006. Linking future ecosystem services and future human well-being. Ecology and Society 11(1):30. https://doi.org/10.5751/ES-01602-110130

Castree, N., W. M. Adams, J. Barry, D. Brockington, B. Büscher, E. Corbera, D. Demeritt, R. Duffy, U. Felt, K. Neves, P. Newell, L. Pellizzoni, K. Rigby, P. Robbins, L. Robin, D. B. Rose, A. Ross, D. Schlosberg, S. Sörlin, P. West, M. Whitehead, and B. Wynne. 2014. Changing the intellectual climate. Nature Climate Change 4(9):763-768. https://doi.org/10.1038/nclimate2339

Chaudhary, S., A. McGregor, D. Houston, and N. Chettri. 2018. Environmental justice and ecosystem services: a disaggregated analysis of community access to forest benefits in Nepal. Ecosystem Services 29:99-115. https://doi.org/10.1016/j.ecoser.2017.10.020

Chisholm, R. A., and B. A. Wintle. 2012. Choosing ecosystem service investments that are robust to uncertainty across multiple parameters. Ecological Applications 22(2):697-704. https://doi. org/10.1890/11-0092.1

Church, A., J. Burgess, and N. Ravenscroft. 2011. Chapter 16: cultural services. UK National Ecosystem Assessment: Technical Report 633-692.

Church, A., R. Fish, R. Haines-Young, S. Mourato, J. Tratalos, L. Stapleton, C. Willis, P. Coates, S. Gibbons, C. Leyshon, M. Potschin, N. Ravenscroft, R. Sanchis-Guarner, M. Winter, and J. Kenter. 2014. UK national ecosystem assessment follow-on. Work Package Report 5: cultural ecosystem services and indicators. UN 
Environment World Conservation Monitoring Centre, LWEC, UK.

Costanza, R., R. de Groot, L. Braat, I. Kubiszewski, L. Fioramonti, P. Sutton, S. Farber, and M. Grasso. 2017. Twenty years of ecosystem services: How far have we come and how far do we still need to go? Ecosystem Services 28:1-16. https://doi. org/10.1016/j.ecoser.2017.09.008

Daw, T., K. Brown, S. Rosendo, and R. Pomeroy. 2011. Applying the ecosystem services concept to poverty alleviation: the need to disaggregate human well-being. Environmental Conservation 38 (4):370-379. https://doi.org/10.1017/S0376892911000506

Daw, T. M., C. Hicks, K. Brown, T. Chaigneau, F. JanuchowskiHartley, W. Cheung, S. Rosendo, B. Crona, S. Coulthard, C. Sandbrook, C. Perry, S. Bandeira, N. A. Muthiga, B. SchulteHerbrüggen, J. Bosire, and T. R. McClanahan. 2016. Elasticity in ecosystem services: exploring the variable relationship between ecosystems and human well-being. Ecology and Society 21(2):11. https://doi.org/10.5751/ES-08173-210211

Dawson, N., and A. Martin. 2015. Assessing the contribution of ecosystem services to human wellbeing: a disaggregated study in western Rwanda. Ecological Economics 117:62-72. https://doi. org/10.1016/j.ecolecon.2015.06.018

de Groot, R., B. Fisher, and M. Christie. 2010. Integrating the ecological and economic dimensions in biodiversity and ecosystem service valuation. Pages 1-40 in P. Kumar, editor. The economics of ecosystems and biodiversity (TEEB): ecological and economic foundations. Earthscan, London, UK.

Dendoncker, N., F. Boeraeve, E. Crouzat, M. Dufrêne, A. König, and C. Barnaud. 2018. How can integrated valuation of ecosystem services help understanding and steering agroecological transitions? Ecology and Society 23(1):12. https://doi. org/10.5751/ES-09843-230112

Dendoncker, N., H. Keune, S. Jacobs, and E. Gómez-Baggethun. 2013. Inclusive ecosystem services valuation. Pages 3-12 in $\mathrm{S}$. Jacobs, N. Dendoncker, and H. Keune, editors. Ecosystem services: global issues, local practices. Elsevier, San Diego, California, USA. https://doi.org/10.1016/B978-0-12-419964-4.00001-9

Díaz, S., S. Demissew, J. Carabias, C. Joly, M. Lonsdale, N. Ash, A. Larigauderie, J. R. Adhikari, S. Arico, A. Báldi, A. Bartuska, I. A. Baste, A. Bilgin, E. Brondizio, K. M. Chan, V. E. Figueroa, A. Duraiappah, M. Fischer, R. Hill, T. Koetz, P. Leadley, P. Lyver, G. M. Mace, B. Martín-López, M. Okumura, D. Pacheco, U. Pascual, E. S. Pérez, B. Reyers, E. Roth, O. Saito, R. J. Scholes, N. Sharma, H. Tallis, R. Thaman, R. Watson, T. Yahara, Z. A. Hamid, C. Akosim, Y. Al-Hafedh, R. Allahverdiyev, E. Amankwah, T. S. Asah, Z. Asfaw, G. Bartus, A. L. Brooks, J. Caillaux, G. Dalle, D. Darnaedi, A. Driver, G. Erpul, P. EscobarEyzaguirre, P. Failler, A. M. M. Fouda, B. Fu, H. Gundimeda, S. Hashimoto, F. Homer, S. Lavorel, G. Lichtenstein, W. A. Mala, W. Mandivenyi, P. Matczak, C. Mbizvo, M. Mehrdadi, J. P. Metzger, J. B. Mikissa, H. Moller, H. A. Mooney, P. Mumby, H. Nagendra, C. Nesshover, A. A. Oteng-Yeboah, G. Pataki, M. Roué, J. Rubis, M. Schultz, P. Smith, R. Sumaila, K. Takeuchi, S. Thomas, M. Verma, Y. Yeo-Chang, and D. Zlatanova. 2015. The IPBES conceptual framework - connecting nature and people.
Current Opinion in Environmental Sustainability 14:1-16. https:// doi.org/10.1016/j.cosust.2014.11.002

Ecosystem Services for Poverty Alleviation (ESPA). 2018. An environment for wellbeing: Pathways out of poverty Policy messages from the ESPA programme. ESPA, Edinburgh, UK.

Ernstson, H. 2013. The social production of ecosystem services: a framework for studying environmental justice and ecological complexity in urbanized landscapes. Landscape and Urban Planning 109(1):7-17. https://doi.org/10.1016/j.landurbplan.2012.10.005

Farhad, S., M. A. Gual, and E. Ruiz-Ballesteros. 2015. Linking governance and ecosystem services: the case of Isla Mayor (Andalusia, Spain). Land Use Policy 46:91-102. https://doi. org/10.1016/j.landusepol.2015.01.019

Felipe-Lucía, M. R., B. Martín-López, S. Lavorel, L. BerraqueroDíaz, J. Escalera-Reyes, and F. A. Comín. 2015. Ecosystem services flows: why stakeholders' power relationships matter. PLoS ONE 10(7):e0132232. https://doi.org/10.1371/journal. pone. 0132232

Fischer, A., and A. Eastwood. 2016. Coproduction of ecosystem services as human-nature interactions: an analytical framework. Land Use Policy 52:41-50. https://doi.org/10.1016/j.

landusepol.2015.12.004

Funtowicz, S. O., and J. R. Ravetz. 1990. Uncertainty and quality in science for policy. Vol. 15. Klumer Academic, Dordrecht, The Netherlands.

García-Nieto, A. P., M. García-Llorente, I. Iniesta-Arandia, and B. Martín-López. 2013. Mapping forest ecosystem services: from providing units to beneficiaries. Ecosystem Services 4:126-138. https://doi.org/10.1016/j.ecoser.2013.03.003

Garcia Rodrigues, J., A. Conides, S. Rivero Rodriguez, S. Raicevich, P. Pita, K. Kleisner, C. Pita, P. Lopes, V. Alonso Roldán, S. Ramos, D. Klaoudatos, L. Outeiro, C. Armstrong, L. Teneva, S. Stefanski, A. Böhnke-Henrichs, M. Kruse, A. Lillebø, E. Bennett, A. Belgrano, A. Murillas, I. Sousa Pinto, B. Burkhard, and S. Villasante. 2017. Marine and coastal cultural ecosystem services: knowledge gaps and research priorities. One Ecosystem 2:e12290. https://doi.org/10.3897/oneeco.2.e12290

Gari, S. R., A. Newton, and J. D. Icely. 2015. A review of the application and evolution of the DPSIR framework with an emphasis on coastal social-ecological systems. Ocean and Coastal Management 103:63-77. https://doi.org/10.1016/j.ocecoaman.2014.11.013

Geijzendorffer, I. R., B. Martín-López, and P. K. Roche. 2015. Improving the identification of mismatches in ecosystem services assessments. Ecological Indicators 52:320-331. https://doi. org/10.1016/j.ecolind.2014.12.016

Gómez-Baggethun, E., B. Martin-López, D. Barton, L. Braat, E. Kelemen, M. Garcia-Llorente, H. Saarikoski, and J. van den Bergh. 2014. State-of-the-art report on integrated valuation of ecosystem services. EU FP7 OpenNESS Project Deliverable 4.1 (July):1-33.

Grêt-Regamey, A., S. H. Brunner, J. Altwegg, and P. Bebi. 2013. Facing uncertainty in ecosystem services-based resource management. Journal of Environmental Management 127:S145S154. https://doi.org/10.1016/j.jenvman.2012.07.028 
Guerry, A. D., S. Polasky, J. Lubchenco, R. Chaplin-Kramer, G. C. Daily, R. Griffin, M. Ruckelshaus, I. J. Bateman, A. Duraiappah, T. Elmqvist, M. W. Feldman, C. Folke, J. Hoekstra, P. M. Kareiva, B. L. Keeler, S. Li, E. McKenzie, Z. Ouyang, B. Reyers, T. H. Ricketts, J. Rockström, H. Tallis, and B. Vira. 2015. Natural capital and ecosystem services informing decisions: from promise to practice. Proceedings of the National Academy of Sciences 112(24):7348-7355. https://doi.org/10.1073/pnas.1503751112

Haines-Young, R. H., and M. B. Potschin. 2009. The links between biodiversity, ecosystem services and human well-being. Pages 110-139 in D. G. Raffaelli and C. L. J. Frid, editors. Ecosystems ecology: a new synthesis. Cambridge University Press, Cambridge, UK. https://doi.org/10.1017/CBO9780511750458.007

Hamel, P., and B. P. Bryant. 2017. Uncertainty assessment in ecosystem services analyses: seven challenges and practical responses. Ecosystem Services 24:1-15. https://doi.org/10.1016/j. ecoser.2016.12.008

Horcea-Milcu, A.-I., J. Leventon, J. Hanspach, and J. Fischer. 2016. Disaggregated contributions of ecosystem services to human well-being: a case study from Eastern Europe. Regional Environmental Change 16(6):1779-1791. https://doi.org/10.1007/ $\underline{\text { s10113-016-0926-2 }}$

Hossain, M. S., F. Eigenbrod, F. Amoako Johnson, and J. A. Dearing. 2017. Unravelling the interrelationships between ecosystem services and human wellbeing in the Bangladesh delta. International Journal of Sustainable Development and World Ecology 24(2):120-134. https://doi.org/10.1080/13504509.2016.1182087

Hou, Y., B. Burkhard, and F. Müller. 2013. Uncertainties in landscape analysis and ecosystem service assessment. Journal of Environmental Management 127:S117-S131. https://doi.org/10.1016/ j.jenvman.2012.12.002

Huntsinger, L., and J. L. Oviedo. 2014. Ecosystem services are social-ecological services in a traditional pastoral system: the case of California's Mediterranean rangelands. Ecology and Society 19(1):8. https://doi.org/10.5751/ES-06143-190108

Iniesta-Arandia, I., M. García-Llorente, P. A. Aguilera, C. Montes, and B. Martín-López. 2014. Socio-cultural valuation of ecosystem services: uncovering the links between values, drivers of change, and human well-being. Ecological Economics 108:36-48. https://doi.org/10.1016/j.ecolecon.2014.09.028

Jacobs, S., B. Martín-López, D. N. Barton, R. Dunford, P. A. Harrison, E. Kelemen, H. Saarikoski, M. Termansen, M. GarcíaLlorente, E. Gómez-Baggethun, L. Kopperoinen, S. Luque, I. Palomo, J. A. Priess, G. M. Rusch, P. Tenerelli, F. Turkelboom, R. Demeyer, J. Hauck, H. Keune, and R. Smith. 2018. The means determine the end - pursuing integrated valuation in practice. Ecosystem Services 29:515-528. https://doi.org/10.1016/j. ecoser.2017.07.011

Jacobs, S., D. Nicolas, B. Martín-López, D. N. Barton, E. GómezBaggethun, F. Boeraeve, F. L. McGrath, K. Vieikko, D. Geneletti, K. J. Sevecke, et al. 2016. A new valuation school: integrating diverse values of nature in resource and land use decisions. Ecosystem Services 22(Part B):213-220. https://doi.org/10.1016/j. ecoser.2016.11.007

Jax, K., and U. Heink. 2016. Human well-being. In M. Potschin and K. Jax, editors. OpenNESS Ecosystem Services Reference
Book. European Centre for Nature Conservation, Tilburg, The Netherlands. [online] URL: http://www.openness-project.eu/ library/reference-book/sp-human-well-being

Jones, L., L. Norton, Z. Austin, A. L. Browne, D. Donovan, B. A. Emmett, Z. J. Grabowski, D. C. Howard, J. P. G. Jones, J. O. Kenter, W. Manley, C. Morris, D. A. Robinson, C. Short, G. M. Siriwardena, C. J. Stevens, J. Storkey, R. D. Waters, and G. F. Willis. 2016. Stocks and flows of natural and human-derived capital in ecosystem services. Land Use Policy 52:151-162. https:// doi.org/10.1016/j.landusepol.2015.12.014

Kovacic, Z. 2015. Complexity theory in quality assessment: case studies in sustainability science for governance. Dissertation. Universitat Autònoma de Barcelona, Barcelona, Spain.

Kroll, F., F. Müller, D. Haase, and N. Fohrer. 2012. Rural-urban gradient analysis of ecosystem services supply and demand dynamics. Land Use Policy 29(3):521-535. https://doi. org/10.1016/j.landusepol.2011.07.008

Kull, C. A., X. A. de Sartre, and M. Castro-Larranaga. 2015. The political ecology of ecosystem services. Geoforum 61:122-134. https://doi.org/10.1016/j.geoforum.2015.03.004

Ledford, H. 2015. How to solve the world's biggest problems. Nature 525(7569):308-311. https://doi.org/10.1038/525308a

Liquete, C., C. Piroddi, E. G. Drakou, L. Gurney, S. Katsanevakis, A. Charef, and B. Egoh. 2013. Current status and future prospects for the assessment of marine and coastal ecosystem services: a systematic review. PLoS ONE 8(7):e67737. https://doi. org/10.1371/journal.pone.0067737

Maes, J., A. Teller, M. Erhard, C. Liquete, L. Braat, P. Berry, B. Egoh, P. Puydarrieux, C. Fiorina, and F. Santos. 2013. Mapping and assessment of ecosystems and their services. European Union, Brussels, Belgium. [online] URL: http://ec.europa.eu/environment/ nature/knowledge/ecosystem_assessment/pdf/MAESWorkingPaper2013. pdf

Martín-López, B., E. Gómez-Baggethun, M. García-Llorente, and C. Montes. 2014. Trade-offs across value-domains in ecosystem services assessment. Ecological Indicators 37:220-228. https://doi.org/10.1016/j.ecolind.2013.03.003

Martínez-Harms, M. J., and P. Balvanera. 2012. Methods for mapping ecosystem service supply: a review. International Journal of Biodiversity Science, Ecosystem Services \& Management 8 (1-2):17-25. https://doi.org/10.1080/21513732.2012.663792

Max-Neef, M. A., A. Elizalde, and M. Hopenhayn. 1998. Desarrollo a escala humana: conceptos, aplicaciones y algunas reflexiones. Icaria, Barcelona, Spain.

McGregor, S. L. 2010. Well-being, wellness and basic human needs in home economics. McGregor Consulting Group, Seabright, Nova Scotia, Canada.

Milanez, B. 2015. Dialogues between social and natural sciences: contribution to the debate on socio-environmental conflicts. Anais da Academia Brasileira de Ciencias 87(4):2335-2348. https:// doi.org/10.1590/0001-3765201520140724

Millennium Ecosystem Assessment. 2005. Ecosystems and human well-being: synthesis. Island, Washington, D.C., USA. 
Moher, D., A. Liberati, J. Tetzlaff, D. G. Altman, and P. Grp. 2009. Preferred reporting items for systematic reviews and metaanalyses: the PRISMA statement (Reprinted from Annals of Internal Medicine). Physical Therapy 89(9):873-880.

Mooney, H. A., A. Duraiappah, and A. Larigauderie. 2013. Evolution of natural and social science interactions in global change research programs. Proceedings of the National Academy of Sciences of the United States of America 110 Suppl(Suppl 1):3665-3672. https://doi.org/10.1073/pnas.1107484110

Narayan, D., R. Chambers, M. K. Shah, and P. Petesch. 2000. Crying out for change. World Bank Publications, New York, New York, USA. https://doi.org/10.1596/0-1952-1602-4

Norgaard, R. B. 2010. Ecosystem services: from eye-opening metaphor to complexity blinder. Ecological Economics 69 (6):1219-1227. https://doi.org/10.1016/j.ecolecon.2009.11.009

Norse, E., and L. Crowder. 2005. Why marine conservation biology? Pages 1-18 in E. Norse and L. Crowder, editors. Marine conservation biology. Island, Washington, D.C., USA.

Outeiro, L., E. Ojea, J. Garcia Rodrigues, A. Himes-Cornell, A. Belgrano, Y. Liu, E. Cabecinha, C. Pita, G. Macho, and S. Villasante. 2017. The role of non-natural capital in the coproduction of marine ecosystem services. International Journal of Biodiversity Science, Ecosystem Services \& Management 13 (3):35-50. https://doi.org/10.1080/21513732.2017.1415973

Palomo, I., M. R. Felipe-Lucía, E. M. Bennett, B. Martín-López, and U. Pascual. 2016. Disentangling the pathways and effects of ecosystem service co-production. Advances in Ecological Research 54:245-283. https://doi.org/10.1016/bs.aecr.2015.09.003

Pappenberger, F., and K. J. Beven. 2006. Ignorance is bliss: or seven reasons not to use uncertainty analysis. Water Resources Research 42(5). https://doi.org/10.1029/2005WR004820

Pereira, E., C. Queirós, H. Pereira, and L. Vicente. 2005. Ecosystem services and human well-being: a participatory study in a mountain community in Portugal. Ecology and Society 10 (2):14. https://doi.org/10.5751/ES-01353-100214

Portman, M. E. 2013. Ecosystem services in practice: challenges to real world implementation of ecosystem services across multiple landscapes - a critical review. Applied Geography 45:185-192. https://doi.org/10.1016/j.apgeog.2013.09.011

Potschin, M., and R. Haines-Young. 2016. Conceptual frameworks and the cascade model. In M. Potschin and K. Jax, editors. OpenNESS Ecosystem Services Reference Book. European Centre for Nature Conservation, Tilburg, The Netherlands. [online] URL: http://www.openness-project.eu/ library/reference-book/cascade-model

Powell, R. B., A. Cuschnir, and P. Peiris. 2009. Overcoming governance and institutional barriers to integrated coastal zone, marine protected area, and tourism management in Sri Lanka. Coastal Management 37(6):633-655. https://doi.org/10.1080/08920750903194272

Reyers, B., R. Biggs, G. S. Cumming, T. Elmqvist, A. P. Hejnowicz, and S. Polasky. 2013. Getting the measure of ecosystem services: a social-ecological approach. Frontiers in Ecology and the Environment 11(5):268-273. https://doi.org/10.1890/120144
Rieb, J. T., R. Chaplin-Kramer, G. C. Daily, P. R. Armsworth, K. Böhning-Gaese, A. Bonn, G. S. Cumming, F. Eigenbrod, V. Grimm, B. M. Jackson, A. Marques, S. K. Pattanayak, H. M. Pereira, G. D. Peterson, T. H. Ricketts, B. E. Robinson, M. Schröter, L. A. Schulte, R. Seppelt, M. G. Turner, and E. M. Bennett. 2017. When, where, and how nature matters for ecosystem services: challenges for the next generation of ecosystem service models. BioScience 67(9):820-833. https://doi. org/10.1093/biosci/bix075

Sardà, R., T. O'Higgins, R. Cormier, A. Diedrich, and J. Tintoré. 2014. A proposed ecosystem-based management system for marine waters: linking the theory of environmental policy to the practice of environmental management. Ecology and Society 19 (4):51. https://doi.org/10.5751/ES-07055-190451

Sas, E., I. Fischhendler, and M. E. Portman. 2010. The demarcation of arbitrary boundaries for coastal zone management: the Israeli case. Journal of Environmental Management 91(11):2358-2369. https://doi.org/10.1016/j. jenvman.2010.06.027

Schlüter, M., R. R. J. McaAllister, R. Arlinghaus, N. Bunnefeld, K. Eisenack, F. Hölker, E. J. Milner-Gulland, B. Müller, E. Nicholson, M. Quaas, and M. Stöven. 2012. New horizons for managing: a review of coupled socio-ecological systems modeling. Natural Resource Modeling 25(1):219-272. https://doi. org/10.1111/j.1939-7445.2011.00108.x

Scholes, R. J., B. Reyers, R. Biggs, M. J. Spierenburg, and A. Duriappah. 2013. Multi-scale and cross-scale assessments of social-ecological systems and their ecosystem services. Current Opinion in Environmental Sustainability 5(1):16-25. https://doi. org/10.1016/j.cosust.2013.01.004

Schröter, M., T. Koellner, R. Alkemade, S. Arnhold, K. J. Bagstad, K.-H. Erb, K. Frank, T. Kastner, M. Kissinger, J. Liu, L. LópezHoffman, J. Maes, A. Marques, B. Martín-López, C. Meyer, C. J. E. Schulp, J. Thober, S. Wolff, and A. Bonn. 2018. Interregional flows of ecosystem services: concepts, typology and four cases. Ecosystem Services 31:231-241. https://doi.org/10.1016/j. ecoser.2018.02.003

Scolozzi, R., E. Morri, and R. Santolini. 2012. Delphi-based change assessment in ecosystem service values to support strategic spatial planning in Italian landscapes. Ecological Indicators 21:134-144. https://doi.org/10.1016/j.ecolind.2011.07.019

Seppelt, R., C. F. Dormann, F. V. Eppink, S. Lautenbach, and S. Schmidt. 2011. A quantitative review of ecosystem service studies: approaches, shortcomings and the road ahead. Journal of Applied Ecology 48(3):630-636. https://doi.org/10.1111/j.1365-2664.2010.01952. $\underline{x}$

Serna-Chavez, H. M., C. J. E. Schulp, P. M. Van Bodegom, W. Bouten, P. H. Verburg, and M. D. Davidson. 2014. A quantitative framework for assessing spatial flows of ecosystem services. Ecological Indicators 39:24-33. https://doi.org/10.1016/j. ecolind.2013.11.024

Spangenberg, J. H., C. Görg, D. T. Truong, V. Tekken, J. V. Bustamante, and J. Settele. 2014. Provision of ecosystem services is determined by human agency, not ecosystem functions. Four case studies. International Journal of Biodiversity Science, 
Ecosystem Services \& Management 10(1):40-53. https://doi. org/10.1080/21513732.2014.884166

Stenseke, M., and A. Larigauderie. 2018. The role, importance and challenges of social sciences and humanities in the work of the intergovernmental science-policy platform on biodiversity and ecosystem services (IPBES). Innovation 31(sup1):S10-S14. https://doi.org/10.1080/13511610.2017.1398076

Stojanovic, T., H. M. McNae, P. Tett, T. W. Potts, J. Reis, H. D. Smith, and I. Dillingham. 2016. The "social" aspect of socialecological systems: a critique of analytical frameworks and findings from a multisite study of coastal sustainability. Ecology and Society 21(3):15. https://doi.org/10.5751/ES-08633-210315

Summers, J. K., L. M. Smith, J. L. Case, and R. A. Linthurst. 2012. A review of the elements of human well-being with an emphasis on the contribution of ecosystem services. Ambio 41 (4):327-340. https://doi.org/10.1007/s13280-012-0256-7

Turner, R. K., and M. Schaafsma. 2015. Coastal zones ecosystem services. Valuation of Ecosystem Services 9:59-75. https://doi. org/10.1007/978-3-319-17214-9

Van Oudenhoven, A., K. Petz, R. Alkemade, L. Hein, and R. S. De Groot. 2012. Framework for systematic indicator selection to assess effects of land management on ecosystem services. Ecological Indicators 21:110-122. https://doi.org/10.1016/j. ecolind.2012.01.012

Villamagna, A. M., P. L. Angermeier, and E. M. Bennett. 2013. Capacity, pressure, demand, and flow: a conceptual framework for analyzing ecosystem service provision and delivery. Ecological Complexity 15:114-121. https://doi.org/10.1016/j.ecocom.2013.07.004

Villamagna, A. M., B. Mogollón, and P. L. Angermeier. 2017. Inequity in ecosystem service delivery: socioeconomic gaps in the public-private conservation network. Ecology and Society 22 (1):36. https://doi.org/10.5751/ES-09021-220136

Viseu, A. 2015. Integration of social science into research is crucial. Nature 525(7569):291. https://doi.org/10.1038/525291a

Walker, W. E., P. Harremoës, J. Rotmans, J. P. van der Sluijs, M. B. A. van Asselt, P. Janssen, and M. P. Krayer von Krauss. 2003. Defining uncertainty: a conceptual basis for uncertainty management in model-based decision support. Integrated Assessment 4(1):5-17. https://doi.org/10.1076/iaij.4.1.5.16466

Walker, W., and M. Haasnoot. 2011. White Paper. Uncertainty analysis and decision-making under uncertainty with the Deltamodel. Deltares, Delft, The Netherlands.

Wei, H., W. Fan, X. Wang, N. Lu, X. Dong, Y. Y. Zhao, X. Ya, and Y. Zhao. 2017. Integrating supply and social demand in ecosystem services assessment: a review. Ecosystem Services 25:15-27. https://doi.org/10.1016/j.ecoser.2017.03.017

Zaucha, J., A. Conides, D. Klaoudatos, and K. Norén. 2016. Can the ecosystem services concept help in enhancing the resilience of land-sea social-ecological systems? Ocean and Coastal Management 124:33-41. https://doi.org/10.1016/j.ocecoaman.2016.01.015 


\section{Appendix 1}

\section{Table A1.1. Complete summary of the results of the literature review}

\begin{tabular}{|c|c|c|c|c|c|c|c|c|c|}
\hline $\begin{array}{l}\frac{y}{0} \\
\frac{0}{0} \\
\text { 㟧 }\end{array}$ & 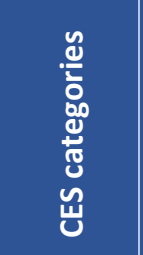 & 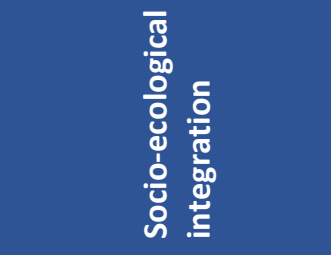 & $\begin{array}{l}\text { 은 } \\
\frac{0}{0} \\
0 \\
\frac{0}{0} \\
0\end{array}$ & 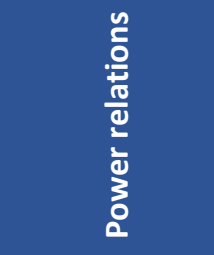 & 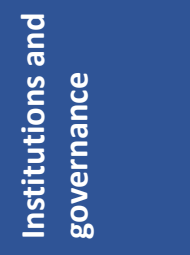 & 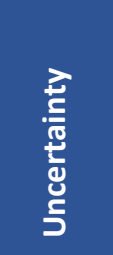 & 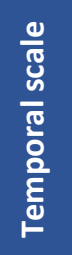 & $\frac{\text { on }}{\frac{10}{8}}$ & 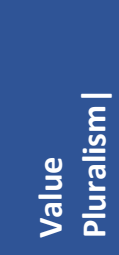 \\
\hline \multirow{3}{*}{$\begin{array}{l}\frac{0}{2} \\
. \frac{0}{c} \\
. \frac{0}{2} \\
\frac{0}{2} \\
\frac{0}{2}\end{array}$} & $\begin{array}{l}\frac{.0}{y} \\
\frac{y}{2} \\
\frac{0}{2} \\
\frac{0}{0} \\
0 \\
\end{array}$ & $\begin{array}{l}\text { Focus on benefit and } \\
\text { capacity of fisheries } \\
\text { and increasingly also } \\
\text { aquaculture. Some } \\
\text { papers also study } \\
\text { flow through fishing } \\
\text { catches and landings }\end{array}$ & $\begin{array}{l}\text { Emphasis on: link } \\
\text { between ecological } \\
\text { conditions and } \\
\text { productivity of } \\
\text { fisheries; } \\
\text { anthropogenic } \\
\text { drivers and impacts } \\
\text { on fisheries. Few } \\
\text { papers describe } \\
\text { institutions and } \\
\text { regulations }\end{array}$ & $\begin{array}{l}\text { Not common. } \\
\text { Some papers } \\
\text { identify } \\
\text { trade-offs } \\
\text { (provisioning } \\
\text { vs. } \\
\text { regulating) } \\
\text { and conflicts } \\
\text { (traditional } \\
\text { fishing vs. } \\
\text { aquaculture). } \\
\text { Very few } \\
\text { study link } \\
\text { between } \\
\text { power } \\
\text { relations and } \\
\text { control of ES }\end{array}$ & $\begin{array}{l}\text { Not } \\
\text { common. } \\
\text { Few papers } \\
\text { identify } \\
\text { actors and } \\
\text { conflicts. } \\
\text { Some } \\
\text { papers } \\
\text { describe } \\
\text { policy and } \\
\text { policy } \\
\text { bodies. } \\
\text { Policy } \\
\text { recommend } \\
\text { ations. }\end{array}$ & $\begin{array}{l}\text { T. Few } \\
M \text { and } \\
\text { E }\end{array}$ & MT & $\begin{array}{l}\text { L, R. } \\
\text { Few } \\
\text { MS, No } \\
\text { CS }\end{array}$ & $\begin{array}{l}\text { Mon. } \\
\text { and } \\
\text { Env. } \\
\text { Very } \\
\text { few SC }\end{array}$ \\
\hline & 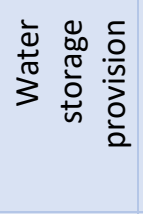 & $\begin{array}{l}\text { Focus on capacity and } \\
\text { benefit of coastal and } \\
\text { marine water for } \\
\text { consumption and } \\
\text { irrigation }\end{array}$ & Not considered & $\begin{array}{l}\text { Not } \\
\text { considered }\end{array}$ & $\begin{array}{l}\text { Not } \\
\text { considered. }\end{array}$ & $\mathrm{T}$ & MT & $\begin{array}{l}\text { L, R. No } \\
\text { MS, No } \\
\text { CS }\end{array}$ & $\begin{array}{l}\text { Mon. } \\
\text { and } \\
\text { Env. }\end{array}$ \\
\hline & 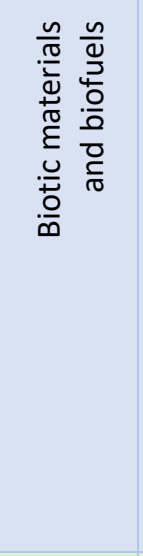 & $\begin{array}{l}\text { Focus on benefits of } \\
\text { mangroves for wood } \\
\text { production }\end{array}$ & $\begin{array}{l}\text { Emphasis on link } \\
\text { between land use } \\
\text { change and } \\
\text { capacity } \\
\text { (mangroves) }\end{array}$ & $\begin{array}{l}\text { Not common. } \\
\text { Few papers } \\
\text { identify } \\
\text { conflicts } \\
\text { (aquaculture } \\
\text { vs. traditional } \\
\text { uses } \\
\text { mangroves) } \\
\text { and trade- } \\
\text { offs (biotic } \\
\text { materials vs. } \\
\text { coastal } \\
\text { protection). }\end{array}$ & $\begin{array}{l}\text { Not } \\
\text { considered. }\end{array}$ & $\mathrm{T}$ & MT & $\begin{array}{l}\text { L,R. } \\
\text { very } \\
\text { few N } \\
\text { and SR. } \\
\text { No MS, } \\
\text { No CS }\end{array}$ & $\begin{array}{l}\text { Mon. } \\
\text { and } \\
\text { Env. } \\
\text { Very } \\
\text { few SC }\end{array}$ \\
\hline 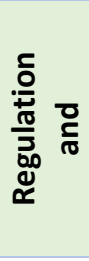 & 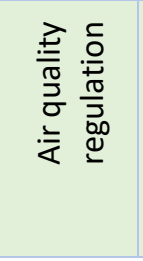 & $\begin{array}{l}\text { Focus on capacity and } \\
\text { benefit of sea water } \\
\text { and coastal } \\
\text { vegetation } \\
\text { (mangroves) for air } \\
\text { regulation }\end{array}$ & $\begin{array}{l}\text { Emphasis on link } \\
\text { between land use } \\
\text { change and } \\
\text { capacity } \\
\text { (mangroves) }\end{array}$ & $\begin{array}{l}\text { Not } \\
\text { considered }\end{array}$ & $\begin{array}{l}\text { Not } \\
\text { considered }\end{array}$ & $\begin{array}{l}\mathrm{T} \text { and } \\
\mathrm{M}\end{array}$ & & $\begin{array}{l}L \text { and } \\
\text { R, Very } \\
\text { few SR. } \\
\text { No MS, } \\
\text { No CS }\end{array}$ & $\begin{array}{l}\text { Mon. } \\
\text { and } \\
\text { Env. }\end{array}$ \\
\hline
\end{tabular}




\begin{tabular}{|c|c|c|c|c|c|c|c|c|}
\hline 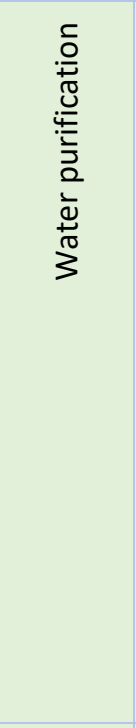 & $\begin{array}{l}\text { Focus on capacity of } \\
\text { concentration of } \\
\text { nutrients or } \\
\text { pollutants in } \\
\text { wetlands, salt } \\
\text { marshes, benthic } \\
\text { invertebrate species } \\
\text { and mangroves. } \\
\text { Some papers study } \\
\text { flow through } \\
\text { retention of excessive } \\
\text { nutrients and } \\
\text { pollutants. Few } \\
\text { papers assess } \\
\text { benefits of water } \\
\text { purification (e.g. } \\
\text { treatment costs) }\end{array}$ & $\begin{array}{l}\text { Emphasis on: link } \\
\text { between ecological } \\
\text { conditions } \\
\text { (eutrophication) } \\
\text { and capacity. Link } \\
\text { between land use } \\
\text { change (agriculture } \\
\text { and urban) and } \\
\text { capacity (wetlands } \\
\text { and salt marshes) }\end{array}$ & $\begin{array}{l}\text { Not common. } \\
\text { Few papers } \\
\text { identify } \\
\text { trade-offs } \\
\text { (water } \\
\text { purification } \\
\text { vs. } \\
\text { Food } \\
\text { provision and } \\
\text { vs. coastal } \\
\text { recreation). }\end{array}$ & $\begin{array}{l}\text { Not } \\
\text { common. } \\
\text { Few papers } \\
\text { identify } \\
\text { actors and } \\
\text { conflicts. } \\
\text { Some } \\
\text { papers } \\
\text { describe } \\
\text { policy and } \\
\text { policy } \\
\text { bodies. } \\
\text { Policy } \\
\text { recommend } \\
\text { ations. }\end{array}$ & $\mathrm{T}$ & $\begin{array}{l}\text { MT. } \\
\text { Few } \\
\text { LT, ST } \\
\text { and } \\
\text { MS }\end{array}$ & $\begin{array}{l}\text { L and } \\
\text { R. Few } \\
\mathrm{N} \text { and } \\
\text { SR. No } \\
\text { MS, No } \\
\text { CS }\end{array}$ & $\begin{array}{l}\text { Mon. } \\
\text { and } \\
\text { Env. }\end{array}$ \\
\hline 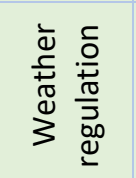 & $\begin{array}{l}\text { Focus on capacity of } \\
\text { coastal vegetation for } \\
\text { local weather } \\
\text { regulation }\end{array}$ & Not considered & $\begin{array}{l}\text { Not } \\
\text { considered }\end{array}$ & $\begin{array}{l}\text { Not } \\
\text { considered }\end{array}$ & $\begin{array}{l}\text { No } \\
\text { data }\end{array}$ & $\begin{array}{l}\text { No } \\
\text { data }\end{array}$ & $\begin{array}{l}\text { L. No } \\
\text { MS, No } \\
\text { CS }\end{array}$ & $\begin{array}{l}\text { No } \\
\text { data }\end{array}$ \\
\hline 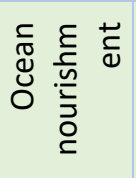 & $\begin{array}{l}\text { Focus on capacity of } \\
\text { nutrient cycle (soil } \\
\text { formation and } \\
\text { nutrients) }\end{array}$ & Not considered & $\begin{array}{l}\text { Not } \\
\text { considered }\end{array}$ & $\begin{array}{l}\text { Not } \\
\text { considered }\end{array}$ & $\begin{array}{l}\mathrm{T}, \mathrm{M} \\
\text { and } \mathrm{E}\end{array}$ & $\begin{array}{l}\text { No } \\
\text { data }\end{array}$ & $\begin{array}{l}\text { L and } \\
\text { R. No } \\
\text { MS, No } \\
\text { CS }\end{array}$ & Env. \\
\hline 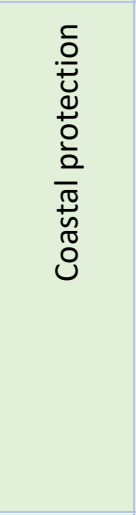 & $\begin{array}{l}\text { Focus on benefit and } \\
\text { capacity of biotic } \\
\text { structures such as } \\
\text { mangroves, wetlands, } \\
\text { coral reefs. Few } \\
\text { papers also asses } \\
\text { flow through coastal } \\
\text { exposure (e.g. wave } \\
\text { attenuation) }\end{array}$ & $\begin{array}{l}\text { Emphasis on: link } \\
\text { between ecological } \\
\text { conditions of biotic } \\
\text { structures } \\
\text { (wetlands, } \\
\text { mangroves, coral } \\
\text { reef) and capacity; } \\
\text { link land use } \\
\text { change (agriculture } \\
\text { and urban) and } \\
\text { capacity } \\
\text { (mangroves) }\end{array}$ & $\begin{array}{l}\text { Not common. } \\
\text { Few papers } \\
\text { identify } \\
\text { trade-offs } \\
\text { (coastal } \\
\text { protection vs. } \\
\text { food } \\
\text { provision, vs. } \\
\text { biotic } \\
\text { materials and } \\
\text { vs. } \\
\text { recreation) }\end{array}$ & $\begin{array}{l}\text { Not } \\
\text { common. } \\
\text { Few papers } \\
\text { identify } \\
\text { actors and } \\
\text { conflicts. }\end{array}$ & $\begin{array}{l}\text { T and } \\
\mathrm{M}\end{array}$ & MT & $\begin{array}{l}\text { L and } \\
\text { R. Very } \\
\text { few } \\
\text { MS, No } \\
\text { CS }\end{array}$ & $\begin{array}{l}\text { Mon. } \\
\text { and } \\
\text { Env. } \\
\text { Very } \\
\text { few SC. }\end{array}$ \\
\hline 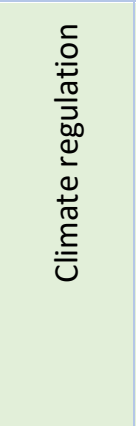 & $\begin{array}{l}\text { Focus on capacity and } \\
\text { benefit of mangroves } \\
\text { for } \mathrm{CO} 2 \\
\text { sequestration and } \\
\text { concentration. No } \\
\text { other climate active } \\
\text { gases are assessed. }\end{array}$ & $\begin{array}{l}\text { Emphasis on link } \\
\text { between land use } \\
\text { change and } \\
\text { capacity } \\
\text { (mangroves) }\end{array}$ & $\begin{array}{l}\text { Not common. } \\
\text { Few identify } \\
\text { conflicts and } \\
\text { power } \\
\text { relations in } \\
\text { PES markets }\end{array}$ & $\begin{array}{l}\text { Few papers } \\
\text { identify } \\
\text { institutional } \\
\text { arrangemen } \\
\text { ts, policies, } \\
\text { actor and } \\
\text { conflicts } \\
\text { Policy } \\
\text { recommend } \\
\text { ations. }\end{array}$ & $\mathrm{T}, \mathrm{E}$ & $\begin{array}{l}\text { MT. } \\
\text { Few } \\
\text { LT } \\
\text { and } \\
\text { MS }\end{array}$ & $\begin{array}{l}\text { L and } \\
\text { R. Very } \\
\text { few, N } \\
\text { and G. } \\
\text { Very } \\
\text { few } \\
\text { MS, No } \\
\text { CS }\end{array}$ & $\begin{array}{l}\text { Env. } \\
\text { and } \\
\text { Mon. }\end{array}$ \\
\hline
\end{tabular}




\begin{tabular}{|c|c|c|c|c|c|c|c|c|c|}
\hline & 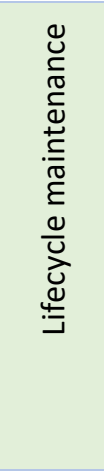 & $\begin{array}{l}\text { Focus on capacity and } \\
\text { benefit of nursery } \\
\text { habitat on } \\
\text { mangroves, seagrass } \\
\text { and } \\
\text { Few papers assess } \\
\text { flow through fish } \\
\text { production and } \\
\text { biodiversity in } \\
\text { nursery habitat }\end{array}$ & $\begin{array}{l}\text { Emphasis on link } \\
\text { between ecological } \\
\text { conditions of } \\
\text { habitats and } \\
\text { capacity. Few } \\
\text { papers describe } \\
\text { institutions and } \\
\text { regulations }\end{array}$ & $\begin{array}{l}\text { Not common. } \\
\text { Few identify } \\
\text { trade- } \\
\text { offs/conflicts } \\
\text { (lifecycle } \\
\text { maintenance } \\
\text { vs. } \\
\text { aquaculture, } \\
\text { vs. fisheries } \\
\text { and vs. } \\
\text { tourism) }\end{array}$ & $\begin{array}{l}\text { Not } \\
\text { common. }\end{array}$ & $\mathrm{T}, \mathrm{E}$ & $\begin{array}{l}\text { MT. } \\
\text { Few } \\
\text { ST }\end{array}$ & $\begin{array}{l}\text { L and } \\
\text { R. Very } \\
\text { few, N } \\
\text { and G. } \\
\text { No MS, } \\
\text { No CS }\end{array}$ & $\begin{array}{l}\text { Env. } \\
\text { and } \\
\text { Mon. }\end{array}$ \\
\hline & 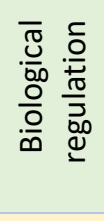 & $\begin{array}{l}\text { Focus on flow of } \\
\text { invasive species and } \\
\text { pathogens }\end{array}$ & Not considered & $\begin{array}{l}\text { Not } \\
\text { considered }\end{array}$ & $\begin{array}{l}\text { Not } \\
\text { considered }\end{array}$ & $\mathrm{T}$ & $\begin{array}{l}\text { No } \\
\text { data }\end{array}$ & $\begin{array}{l}\text { L and } \\
\text { R. very } \\
\text { few G. } \\
\text { No MS, } \\
\text { No CS }\end{array}$ & Env. \\
\hline \multirow{3}{*}{$\begin{array}{l}\overline{\frac{0}{5}} \\
\frac{\mathrm{m}}{3}\end{array}$} & 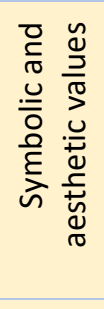 & $\begin{array}{l}\text { Focus on benefit of } \\
\text { aesthetic values such } \\
\text { as sea views, coastal } \\
\text { landscape and } \\
\text { heritage }\end{array}$ & $\begin{array}{l}\text { Emphasis on link } \\
\text { between human } \\
\text { pressures and } \\
\text { impacts on } \\
\text { aesthetic values } \\
\text { (degradation of } \\
\text { landscape wildness) }\end{array}$ & $\begin{array}{l}\text { Not } \\
\text { considered }\end{array}$ & $\begin{array}{l}\text { Not } \\
\text { considered }\end{array}$ & $\begin{array}{l}\mathrm{M}, \mathrm{E} \\
\text { and } \mathrm{O}\end{array}$ & MT & $\begin{array}{l}\text { L and } \\
\text { R. very } \\
\text { few SR, } \\
\mathrm{N} \text { and } \\
\text { G. No } \\
\mathrm{MS} \text {, No } \\
\mathrm{CS}\end{array}$ & $\begin{array}{l}\text { Mon. } \\
\text { and SC }\end{array}$ \\
\hline & 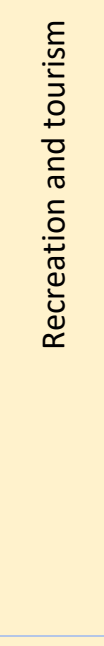 & $\begin{array}{l}\text { Focus on benefits of } \\
\text { tourism and tourist } \\
\text { value preferences. } \\
\text { Some papers assess } \\
\text { flow of natural } \\
\text { resources } \\
\text { (mangroves, } \\
\text { biodiversity) for } \\
\text { tourism and } \\
\text { recreational } \\
\text { activities. Few papers } \\
\text { assess capacity of } \\
\text { ecosystem for } \\
\text { bathing, biodiversity } \\
\text { and naturalness }\end{array}$ & $\begin{array}{l}\text { Emphasis on: socio- } \\
\text { economic context; } \\
\text { link between } \\
\text { human pressures } \\
\text { and impacts on } \\
\text { ecological } \\
\text { conditions or } \\
\text { wildness }\end{array}$ & $\begin{array}{l}\text { Not common. } \\
\text { Few papers } \\
\text { study value } \\
\text { diversity } \\
\text { conflicts } \\
\text { among actors } \\
\text { (e.g. tourist } \\
\text { vs. residents) }\end{array}$ & $\begin{array}{l}\text { Not } \\
\text { common. } \\
\text { Few papers } \\
\text { identify } \\
\text { actors and } \\
\text { conflicts. }\end{array}$ & $\begin{array}{l}T \text { and } \\
M\end{array}$ & MT & $\begin{array}{l}\mathrm{L} \text { and } \\
\text { R. No } \\
\text { MS, No } \\
\text { CS }\end{array}$ & $\begin{array}{l}\text { Mon. } \\
\text { and SC }\end{array}$ \\
\hline & 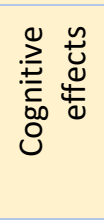 & $\begin{array}{l}\text { Focus on benefit of } \\
\text { research and } \\
\text { education } \\
\text { (institutions and } \\
\text { public policy) }\end{array}$ & Not considered & $\begin{array}{l}\text { Not } \\
\text { considered }\end{array}$ & $\begin{array}{l}\text { Not } \\
\text { considered }\end{array}$ & $\begin{array}{l}\mathrm{M} \text { and } \\
\mathrm{E}\end{array}$ & MT & $\begin{array}{l}\mathrm{L} \text { and } \\
\text { R. No } \\
\text { MS, No } \\
\text { CS }\end{array}$ & $\begin{array}{l}\text { Mon. } \\
\text { and SC }\end{array}$ \\
\hline
\end{tabular}

Table 1. The majority of the reviewed manuscripts contain significant gaps regarding socio-ecological components. They fail to integrate some of the cascade components, especially flow. The papers do not completely embrace coproduction and power relations, and neither do they assess uncertainty, value pluralism and spatial and temporal scales interactions. $\dagger \mathrm{T}=$ Technical; $\mathrm{M}=$ Methodological; $\mathrm{E}=$ Epistemological; $\mathrm{O}=$ Ontological $\neq \mathrm{MT}=$ Medium-term; $\mathrm{ST}=$ Short-term; MS=Multiscale; $\mathrm{CS}=$ Cross-scale $\S \mathrm{L}=$ Local; R=Regional; $\mathrm{LT}=$ Long-term. |Mon.= Monetary; Env.= Environmental; SC.= Sociocultural. 